OPEN ACCESS

Edited by:

Aldo Torre,

Instituto Nacional de Ciencias Médicas y Nutrición Salvador Zubirán (INCMNSZ), Mexico

Reviewed by:

Ling Yang,

Huazhong University of Science and

Technology, China Hua Wang

Anhui Medical University, China

${ }^{*}$ Correspondence:

Marcello Persico mpersico@unisa.it

Specialty section:

This article was submitted to Gastroenterology,

a section of the journal

Frontiers in Medicine

Received: 22 September 2021 Accepted: 05 November 2021 Published: 09 December 2021

Citation:

Torre P, Motta BM, Sciorio R Masarone $M$ and Persico M (2021) Inflammation and Fibrogenesis in MAFLD: Role of the Hepatic Immune

System. Front. Med. 8:781567. doi: 10.3389/fmed.2021.781567

\section{Inflammation and Fibrogenesis in MAFLD: Role of the Hepatic Immune System}

\author{
Pietro Torre ${ }^{1}$, Benedetta Maria Motta ${ }^{2}$, Roberta Sciorio ${ }^{1}$, Mario Masarone ${ }^{1}$ and \\ Marcello Persico ${ }^{1 *}$ \\ 1 Internal Medicine and Hepatology Unit, Department of Medicine, Surgery and Dentistry, "Scuola Medica Salernitana", \\ University of Salerno, Salerno, Italy, ${ }^{2}$ Department of Medicine, Surgery and Dentistry, "Scuola Medica Salernitana", University \\ of Salerno, Baronissi, Italy
}

Metabolic (dysfunction)-associated fatty liver disease (MAFLD) is the definition recently proposed to better circumscribe the spectrum of conditions long known as non-alcoholic fatty liver disease (NAFLD) that range from simple steatosis without inflammation to more advanced liver diseases. The progression of MAFLD, as well as other chronic liver diseases, toward cirrhosis, is driven by hepatic inflammation and fibrogenesis. The latter, result of a "chronic wound healing reaction," is a dynamic process, and the understanding of its underlying pathophysiological events has increased in recent years. Fibrosis progresses in a microenvironment where it takes part an interplay between fibrogenic cells and many other elements, including some cells of the immune system with an underexplored or still unclear role in liver diseases. Some therapeutic approaches, also acting on the immune system, have been probed over time to evaluate their ability to improve inflammation and fibrosis in NAFLD, but to date no drug has been approved to treat this condition. In this review, we will focus on the contribution of the liver immune system in the progression of NAFLD, and on therapies under study that aim to counter the immune substrate of the disease.

Keywords: NAFLD, MAFLD, liver immunology, immunometabolism, liver fibrogenesis, NAFLD therapies

\section{INTRODUCTION: DEFINITIONS, CHANGE OF TERMINOLOGY, AND EPIDEMIOLOGY}

MALFD stands for "metabolic (dysfunction)-associated fatty liver disease" and is a recently recommended term by an international panel of experts (1) to replace the long used NAFLD (nonalcoholic fatty liver disease) and NASH (non-alcoholic steatohepatitis). The latter was coined by Ludwig et al., referring to the fatty liver and inflammation observed in biopsy specimens of patients who had other metabolic disorders, such as obesity or related conditions, and were not alcohol abusers (2), while NAFLD appeared for the first time in a paper by Schaffner and Thaler (3). According to EASL and AASLD guidelines, NAFLD indicates an excessive accumulation of liver fat, corresponding to the presence of steatosis in $>5 \%$ of hepatocytes, documented by liver histology or imaging, in people who don't drink an at-risk amount of alcohol (nor having other causes of steatosis). The latter specification is believed to represent a weak point in this definition, due to the absence of an international consensus in defining threshold levels for at-risk alcohol consumption and the potential shame associated with the term "alcoholic" (1,4-6). NAFLD term includes a set of pathological conditions ranging from mild alterations (NAFL) to others conferring a worse 
prognosis (NASH, which implies hepatocyte injury and liver fibrosis of increasing severity up to NASH-cirrhosis, and hepatocarcinoma). On the other hand, the Asian Pacific Association for the Study of the Liver (APASL) has already presented guidelines on the diagnosis and management of MAFLD (7). The open challenge is to find out the causes why some people with NAFLD progress to advanced liver disease while others do not (8).

The agreement on the term "MAFLD" originated to emphasize the metabolic etiology of this spectrum of conditions, and consequently avoid the use of a "non-definition" (1). Moreover, with this new term the coexistence of other cofactors for the progression of the disease, including alcohol consumption, is allowed $(1,6)$. Experts proposed that the term MAFLD should include the set of conditions, overcoming the non-NASH/NASH dichotomy and that it should be enriched with data on the severity of the disease (grade of activity and stage of fibrosis) (1). The issue of the terminology of NAFLD and NASH is not new, in fact was already addressed in the past $(1,9)$. However, skepticism is not absent regarding the recently proposed change, which according to some authors could be precocious and counterproductive (10). Their doubts concern the use of a term ("metabolic") that likewise may lack specificity; because other liver diseases (also responsible for hepatic steatosis, e.g., Wilson disease) have a metabolic etiology; since, although knowledge of pathophysiology and other aspects of NAFLD has increased, great challenges still exist; furthermore, they believe this change could have negative repercussions for socio-sanitary and scientific reasons (10).

NAFLD is estimated to have a global prevalence of around $25 \%$ of the general population and is responsible for high morbidity and mortality, having been found that its prevalence has grown in tandem with the global increase of obesity $(8,11-$ 13). It is an increasingly common cause of liver transplantation and hepatocarcinoma, which in NAFLD can arise even in the absence of cirrhosis (8). In addition to liver-related causes of morbidity and mortality, it has a strong link with the various components of the metabolic syndrome (MetS) (8); in fact, NAFLD showed to have a high prevalence in patients with MetS elements $(12,14)$. It was also observed that, over the years, people with NAFLD have a high probability of developing other metabolic comorbidities, cardiovascular diseases, and non-fatal or fatal events (the latter representing the leading cause of death for these patients), compared to those without NAFLD $(8,13$, $15,16)$, and that patients with cardiovascular disease (CVD) risk factors have an increased risk of developing NAFLD compared to people without these risk factors, suggesting a bi-directional relationship between NAFLD and CVD risk factors (15). The cardiovascular risk for patients with NAFLD, which is especially observed for those who have NASH, appears to be independent of the various components of the metabolic syndrome, suggesting a direct role of the liver disease $(16,17)$. Despite its strong negative impact on human health, to date, there are still no approved therapies to reverse this condition. The chronic inflammation which occurs in NASH is a central pathophysiological event and guides the progression of the disease through increasing degrees of fibrosis toward liver cirrhosis.

\section{HOMEOSTASIS OF THE LIVER IMMUNE SYSTEM IN HEALTH STATE}

The liver is crucial in the metabolism of carbohydrates, lipids, and proteins, is responsible for bile formation, detoxification and inactivation of substances, and has storage functions, but it is also an important immune organ (18). In the hepatic parenchyma, a rich variety of elements participating in the immune response exists (19), some of which being not strictly immune cells. Among the latter there are hepatocytes, the most abundant cell population of the liver, which, in addition to their "primary" functions, express Pattern Recognition Receptors (PRRs), can produce acute phase proteins, cytokines, chemokines, complement proteins and other opsonins; they produce proteins involved in iron metabolism, such as hepcidin, the availability of this element being able to affects bacterial proliferation; hepatocytes are the main source of LPS-binding protein, soluble CD14, and soluble MD-2, which participate in the formation of TLR4-MD-2-LPS complex, from which, in turn, starts the signaling that leads to NF-kB activation and inflammatory responses; fibrinogen, produced by hepatocytes, participates in the immune response as it mediates the adhesion of leukocytes, can activate the complement system, and because its active fragment fibrin has antibacterial properties; moreover, they express MHC-I and in some conditions also MHC-II, lacking, however, in the expression of costimulatory molecules (18-22), liver sinusoidal endothelial cells (LSECs, which in addition to offering a physical barrier between the lumen of the sinusoid and the space of Disse, participate in the process of leukocytes transmigration, exhibit scavenger activity, are capable of endocytosis, express TLRs and MHC molecules, and are involved in tolerance mechanisms, by direct action on $\mathrm{T}$ lymphocytes, e.g., by PDL1 expression, or through the "veto" function, consisting in vetoing the ability of other APCs, like dendritic cells, to activate $\mathrm{T}$ lymphocytes, in a mode requiring physical contact but MHC-independent) (19, 23-28), biliary epithelial cells (BECs, antigen presentation, TLRs expression, production of inflammatory mediators in response to insults; these cells were found capable of "endotoxin tolerance," which was demonstrated after observation that human intrahepatic biliary epithelial cell lines pretreated with LPS developed tolerance to further stimulation with such substance; this effect was attributed to the negative regulation of the TLR signaling mediated by interleukin-1 receptor-associated kinase M, IRAKM) $(19,29)$, and hepatic stellate cells (HSCs, the main actors in the fibrogenesis process, also express TLRs, MHC-I, MHCII, and CD1 molecules, and, as observed for the LSECs, are involved in the induction of T-cell tolerance also through a veto function) $(19,22,30)$. These cells are part of innate immunity, but also interact with elements of adaptive responses. Among the innate immune cells housed in liver sinusoids there are myeloid- (Kupffer cells, KC, dendritic cells, DCs, myeloid-derived suppressor cells, MDSC) or lymphoid-derived cells (such as natural killers, NK, and innate lymphoid cells, ILCs). Other abundant elements do not reflect either the innate or adaptive system criteria and were therefore defined as "innate-like," or "unconventional" lymphocytes. These include 
mucosal-associated invariant $\mathrm{T}$ (MAIT) cells, which are today deemed to be a leading share of hepatic $\mathrm{T}$ lymphocytes in the healthy liver (31), natural killer T (NKT) cells, and $\gamma \delta$-T cells. Furthermore, the healthy liver also hosts conventional $\mathrm{T}$ and B lymphocytes (adaptive immunity) (19). Compared to other lymphoid organs, such as the lymph nodes and the spleen, the liver greatly differs in terms of composition of its resident cells (32).

A complex relationship between the large number of antigens to which cells of healthy liver are continuously exposed and the maintenance of an immune homeostasis exists: the liver occupies a first-line position, filtering more than 2,000 liters of blood per day coming from the portal vein, which in turns carries a large amount of gut-derived food antigens and bacterial products (e.g., LPS), and from the hepatic artery which transports oxygen-rich blood (22). Furthermore, in the liver it occurs the formation of neo-antigens due to the intrahepatic transformation of many compounds (32). Under stationary conditions, the hepatic immune cells maintain tolerance to non-harmful substances (e.g., food-derived antigens), but they must also be able to mount an adequate response against the pathogenetic ones $(22,32)$. The tolerance state originates in a tolerogenic microenvironment, due to the complex interplay that takes place between different cells. In fact, liver resident cells block adaptive immune responses by inducing states of energy, exhaustion, deviation, or by leading immune cells to apoptosis $(22,33)$. The concept of hepatic tolerance was initially hypothesized in the 60 's by observing long-term survivals of allogeneic pig liver transplants without using immunosuppression $(34,35)$, a phenomenon subsequently confirmed in other animal models (36). Furthermore, the finding that liver transplanted animals receiving non-hepatic allografts from the same liver donor showed acceptance of such grafts, suggested that the liver can induce systemic T-cell tolerance (36).

Among the mechanisms responsible for liver immune tolerance, there is the expression by liver cells of MHC complexes in the absence of costimulatory molecules (e.g., CD80/CD86); lack of MHC-II expression; release of cytokines with suppressor activity, such as IL 10 or TGF- $\beta$; exposure of immune cells to programmed cell death ligand-1 (PD-L1), or Fas-L; phagocytosis by Kupffer cells; inhibition of professional APC activating function $(19,30,32,37,38)$. In the context of liver transplants specific mechanisms inducing tolerance take part (36). Since tolerance has been observed to be a marked phenomenon in the liver, hypotheses have been formulated to explain this occurrence (33). In the "graveyard hypothesis" the liver was conceived as a site where T lymphocytes that are already directed toward apoptosis ("moribund" lymphocytes) are sequestered, whereas the "killing field hypothesis" suggests that this organ may be a site in which activated $\mathrm{T}$ lymphocytes accumulate, and where tolerance mechanisms lead them to apoptosis (39). The "school" model was another suggested theory, and postulates that lymphocytes migrating through the liver are educated (like "students") to have regulatory functions rather than participate in immunosurveillance; in this model, the hepatic antigen presenting cells (hepatocytes, LSECs, KCs, DCs, HSCs) represent the "teachers" who induce such lymphocytes to a regulatory state, this action being favored by the anatomy of the hepatic sinusoids (40). Another modality of hepatic immune homeostasis maintenance was observed to depend on liver draining lymph nodes (LNs), differently depending on which one is considered, having been found that portal LN is a site of regulatory $\mathrm{T}$ cells induction, whereas the celiac $\mathrm{LN}$ is involved in $\mathrm{T}$ cell responses $(33,41)$.

Bile acids and the extracellular matrix (as described below) can also modulate the immune response in the liver (19, 42, 43). Moreover, cellular metabolism is closely linked to immune properties. In fact, different metabolic patterns have been found associated with different immune cell functions. A predominantly glycolytic metabolism was observed in different types of effector T lymphocytes and other activated immune cells with effector function participating in inflammatory processes, while fatty acid oxidation was observed to be preferred by noninflammatory immune cells (e.g., regulatory T cells, $\left.\mathrm{T}_{\text {reg }}\right)(44,45)$. Moreover, it was observed that glycolysis induced by HIF-1 $\alpha$ on the one hand, and oxidative metabolism induced by IL-4 / STAT6 / PGC-1 $\beta$ on the other hand, drove different types of macrophage phenotypes, proinflammatory (46) vs. alternative (anti-inflammatory) (47), respectively (48).

In contrast to the immune homeostasis of the healthy liver, which nevertheless is capable of effective local or systemic inflammatory responses, in NAFLD, cells with immune functions become key players in the disease progression.

\section{NAFLD IS A MULTIFACTORIAL, SYSTEMIC DISEASE CAUSED BY A SET OF SIMULTANEOUS AND SYNERGISTIC EVENTS}

The "two-hit" model for NAFLD progression was proposed in 1998 by C. P. Day and O. F. James. In this theory, the first hit is the excess in the accumulation of lipids within hepatocyte (steatosis), and the second one corresponds to other factors responsible for steatohepatitis (49). The currently accepted theory, "multiple-hit hypothesis," proposed by Tilg and Moschen (50), replaced the two-hit model and indicates that there are multiple synergistic events leading to liver inflammation, proceeding in parallel. In this theory, inflammation not necessarily follows the fat accumulation, being the opposite also plausible: inflammation caused by different insults could exist before steatosis in NASH, and may contribute to its progression (50). Several factors contribute to this pathological condition, including insulin resistance, which is a central event in the NAFLD pathophysiology, excess flow of fatty acids to the liver, lipotoxicity, mitochondrial dysfunction, oxidative stress, endoplasmic reticulum stress (50, 51). Altered liver-adipose tissue cross talk (because of the effect on the liver of the imbalance of adipokine production by a dysfunctional adipose tissue) $(50,51)$ and gut-liver axis, are important dysfunctions occurring in NAFLD and implicated in its pathogenesis (50). Patients with NAFLD showed to have changes in gut microbiota, a high prevalence of intestinal bacterial overgrowth, and increased gut permeability (52-54). The increased liver exposure to bacterial derived products 
(e.g., endotoxemia), proved to cause liver fat accumulation and inflammation mediated by immune system cells (e.g., Kupffer cells via TLR-4) $(51,55)$. Among the genetic factors conferring susceptibility to NAFLD there are polymorphisms in patatin-like phospholipase domain containing-3 (PNPLA3) gene, which is the most studied in NAFLD, transmembrane 6 superfamily, member 2 (TM6SF2) gene, membrane bound O-acyltransferase domain containing 7-transmembrane channel-like 4 (MBOAT7) gene, glucokinase regulator (GCKR) gene, and 17-beta hydroxysteroid dehydrogenase-13 (HSD17B13) gene $(8,56)$; moreover, variants of genes regulating the mitochondrial activity, insulin signaling, and immune response have also been shown to be involved in such disease (57). Epigenetic changes, such as altered DNA methylation and miRNA expression, have recently been investigated in NAFLD and linked to disease progression (5860 ). Environmental risk factors affect the onset and progression of fatty liver and include dietary styles like Western diet (high in saturated fats), high consumption of fructose (e.g., that contained in some sweetened beverages or high fructose corn syrup) and refined carbohydrates, and sedentary lifestyle. The prevalence of NAFLD also varies in relation to age, sex, and ethnicity $(4,8$, $51,61)$. It should be noted, however, that not a single risk factor but the interplay of many elements causes NAFLD progression; in fact, not all obese or people with risk factors for NAFLD are affected by this condition, and NAFLD can develop in non-obese, non-diabetic people (8).

The concept of metabolic flexibility (opposed to metabolic inflexibility) indicates the ability to adjust the utilization of substrates depending on different conditions (e.g., changes in their availability) $(8,62)$. The typical alterations observed in NAFLD patients (high triglycerides, FFAs, and insulin) led to the hypothesis that it could be a condition characterized by metabolic inflexibility (8). A key element for the pathogenesis of NAFLD is the excess of fat and lipotoxicity $(51,63,64)$. The latter, rather than the excess of fat alone, is associated with disease progression (65). The excess of circulating FFAs and the consequent abnormal liver uptake and fat accumulation typical of NAFLD, derives from abnormal lipolysis (hydrolysis of triglyceride) in the adipose tissue, mediated by insulin resistance, which is the event responsible for the largest share of hepatic fat accumulation, increased de novo lipogenesis (starting from glucose or fructose), and excess in dietary fat intake $(64,66,67)$. Fatty acids in the liver are addressed to oxidation (mitochondrial $\beta$-oxidation, or oxidation in peroxisomes, or microsomes) or are esterified to triglycerides (TGs), to form very low-density lipoprotein (VLDL) particles, which will be secreted, or lipid droplets, which will be stored in the hepatocytes $(63,64,67)$. Triglycerides formation, although associated with steatosis, is thought to be a protective response to an excess of fats, as it will be stored in an inert, non-toxic form $(50,63,67,68)$. Saturation of the processes responsible FFAs handling, due to the large amount that reaches the hepatic parenchyma, leads to alterations in mitochondrial function and an increase in the production of reactive oxygen species (ROS) (69). This ROS increase is not effectively counteracted and in NAFLD it was found an inefficiency of the ROS detoxification systems (70). The resulting oxidative stress also causes lipid damage by lipid peroxidation, which results in the formation of compounds (e.g., 4-hydroxy2-nonenal, 4-HNE, and malondialdehyde, MDA) that contribute to the disease progression $(69,71,72)$. However, it is still unclear whether mitochondrial dysfunction is a consequence of NAFLDassociated alterations or an upstream condition that predisposes to NASH $(66,73)$. The oxidative stress that occurs in NAFLD is in close association with activation of the immune system, e.g., ROS are a stimulus for the activation of Kupffer cells (KCs), which in turn will become ROS producers $(74,75)$. Lipotoxicity refers to cell dysfunctions and injury caused by lipids; saturated fatty acids such as palmitic acid and stearic acid, lysophosphatidylcholine, free cholesterol, and ceramides are considered lipotoxic species $(65,76,77)$. Lipotoxicity leads to endoplasmic reticulum stress, altered autophagy, release of extracellular vehicles (EVs), and, ultimately, to activation of cell death pathway $(64,67,78$, 79). EVs, which are distinguished by size in exosomes (up to $100 \mathrm{~nm}$ in diameter) and microparticles (from 100 to $1,000 \mathrm{~nm}$ ), are involved in cell-cell communication (80), and during lipotoxicity-induced hepatocytes injury they would contribute to the liver damage by eliciting pro-inflammatory responses [e.g., by inducing the release of inflammatory cytokines in macrophages (65, 81-83); moreover, they were found to be internalized by HSCs and cause their activation (81)]. Given their role in NAFLD, EVs were proposed as a marker of diseases progression (65).

Figure 1 illustrates the risk factors for NAFLD, the molecular events underlying its progression, and the histological features found in the distinct entities of its spectrum.

\section{THE FIBROGENESIS PROCESS IN NAFLD}

The hepatocytes injury and death, caused in NAFLD by metabolic dysfunctions, lead to the release of warning signals which are responsible for recruitment and activation of immune and fibrogenic cells. These cells amplify the pathological process by releasing pro-inflammatory and pro-fibrogenic factors, thus creating a vicious circle $(69,84-88)$.

Fibrogenesis has the physiological role of repairing a damaged tissue, so acting as a wound healing response. However, regardless of etiology, chronic liver injury and inflammation and the consequent fibrogenesis, over the years, can lead to progressive fibrosis, which in turn can evolve to liver cirrhosis, a silent condition until its complications appear, which is associated with high morbidity and mortality $(8,65)$. Abnormal hepatic fibrogenesis is a dynamic process in which an excess of production and a progressive accumulation over time of extracellular matrix (ECM) components takes part. In fact, in pathological conditions, the regulation of the amount of matrix, as a result of deposition and reabsorption processes, is not guaranteed (65).

Normal ECM is composed of different classes of components, including several types of fibrillary and non-fibrillar collagens, non-collagenous proteins (such as fibronectin, laminin, and elastin), and proteoglycans (89). In a proteomics study of healthy liver tissue samples, it was observed that the ECM is made up of more than 100 distinct ECM proteins (90). In physiological conditions, ECM is directly produced by many cell types 


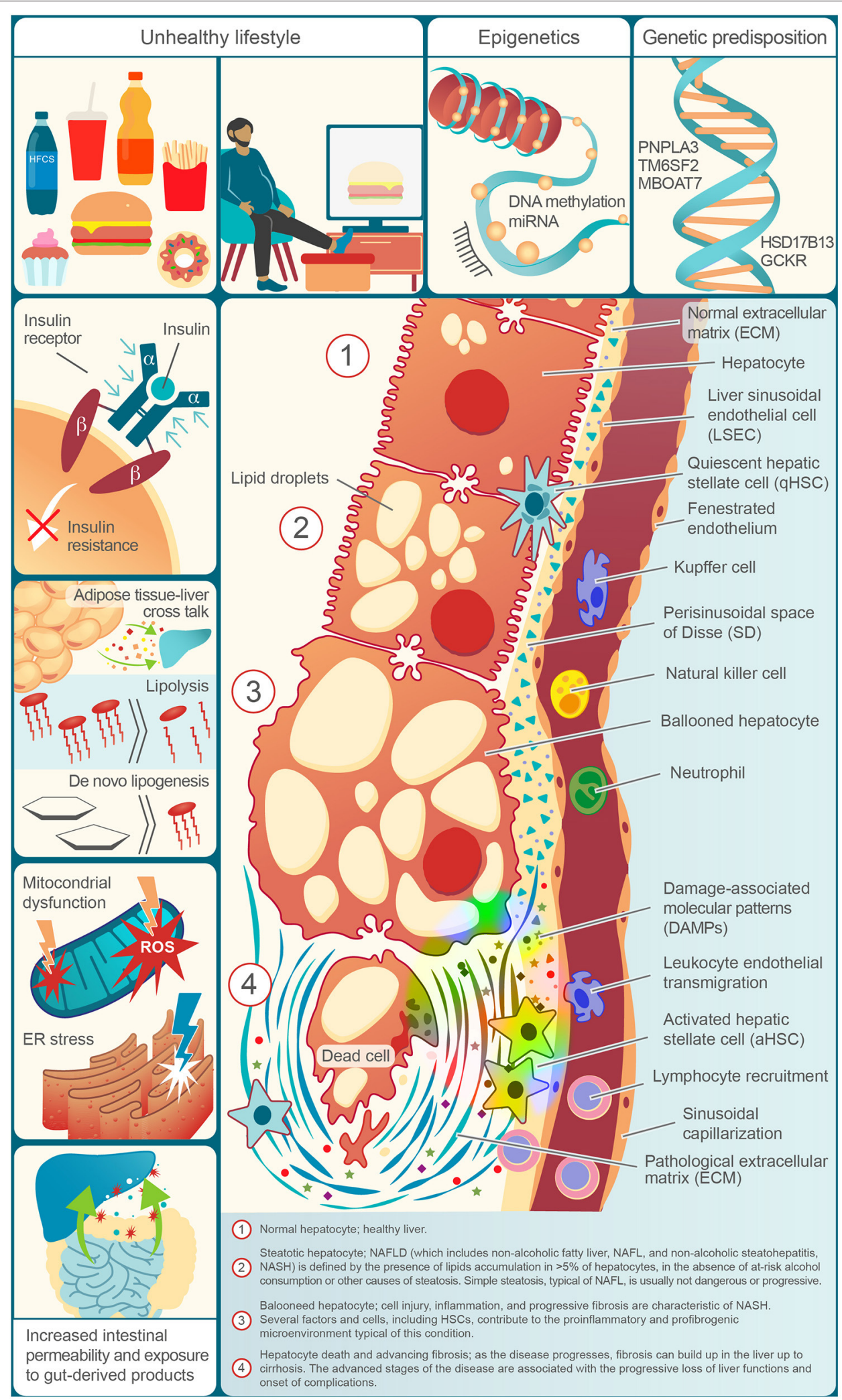

FIGURE 1 | Risk factors, physiopathological molecular events, and typical elements of the NAFLD spectrum in a decorative, cell by cell, succession 
(HSCs, hepatocytes, LSECs, cholangiocytes) (91). Furthermore, these cells release matrix metalloproteinase (MMPs), the major class of enzymes responsible for ECM degradation, and tissue inhibitors of metalloproteinases (TIMPs). For the maintenance of homeostasis, there is a fine balance between the activity of MMPs and that of TIMPs (92). In an experimental model of liver fibrosis, increased activity of TIMP-1 was found to be associated with a decreased spontaneous hepatic fibrosis resolution (93). In the healthy liver, anyway, the ECM occupies only a small part of the entire parenchyma; in the space of Disse, it forms a thin and discontinuous layer (94).

HSCs are the main source of ECM-producing fibroblasts $(65,89)$. In normal liver, these cells are localized in the space of Disse, and by their dendritic processes, they interact with hepatocytes and other adjacent elements of the liver parenchyma (65). Here they are involved in ECM homeostasis, work as a deposit of vitamin A (of which they are the main repository), and have immune functions $(65,95)$. After activation and trans-differentiation, they transform into myofibroblastlike cells (HSC/MFs) which abundantly proliferate and produce EC matrix, migrate in response to chemoattractants, produce proinflammatory mediators, thus directly contributing to the "profibrogenic environment," and have more marked contractile properties (65). Their contraction can also influence the portal pressure (96). In addition to HSCs, a smaller proportion of fibrogenic cells derives from portal fibroblasts, but other cells of origin have also been described, such as bone marrowderived precursor, hepatocytes and cholangiocytes (reflecting a process of "epithelial-to-mesenchymal transition," EMT) (97), or mesothelial cells (MCs), although the contribution of these cells to liver MFs is believed to be minor or questionable (65). It has been hypothesized that ECM and the activity of the HSCs during NASH could have a beneficial role in the early stages of disease being, on the other hand, detrimental in later stages (89).

Activation of HSCs includes initiation and progression phases, occurs in an inflammatory context, and depends on the interaction with many elements, including immune system cells which promote and sustain the fibrogenesis process by producing several mediators $(65,91)$. Among these, a crucial role is played by profibrogenic cytokines. Transforming growth factor$\beta$ (TGF $\beta$ ) is released by different cell types and is considered the most potent fibrogenic cytokine and activator of HSCs, leading to the production of type I collagen through a signaling pathway that involves Smad proteins $(65,89,98-100)$. Phagocytosis of apoptotic cells by macrophages was found in vitro to increase the release of TGF $\beta$ (101), and also the HSCs were found capable of phagocytizing apoptotic bodies, this event having been found to be causative of profibrogenic responses (102); these results defined a link between hepatocytes death and fibrogenesis (102). Platelet-derived growth factor (PDGF) is another pro-fibrogenic cytokine, which leads to the proliferation and migration of HSCs $(100,103)$. Other cytokines involved in HSCs activation or proliferation include VEGF, CTGF, and IL-17 (65, 89, 100, 104). Furthermore, leptin showed to exert profibrotic effects, while adiponectin exhibited antifibrogenic properties (105).

Damaged or dead hepatocytes during NAFLD release damageassociated molecular patterns (DAMPs), which can activate the
HSCs by toll-like receptors (TLRs) $(89,106)$, and TLRs on HSCs also perceive microbial products (such as LPS), which increase due to the altered intestinal permeability associated with NAFLD, resulting in activation of these cells $(100,107,108)$. Hepatocyte derived hedgehog $(\mathrm{Hh})$ ligands and osteopontin (OPN) were found capable of activating HSCs in NAFLD $(109,110)$. Another emerging signaling pathway for HSCs activation is the Hippo pathway, which involves the Yes-associated protein (YAP) (89, 111). Among the different stimuli that have been found to activate the HSCs $(65,112)$, there is the accumulation in these cells of free cholesterol (FC), which was found to lead to an increase of TLR4 expression and to sensitize HSCs to the action of TGF $\beta$ (113).

ECM is considered an active biological system, with immunomodulating properties. In fact, it can directly influence the activity of cells participating in the progression of NAFLD. Some components of the ECM include domains that can interact with immune system receptors, having anti- or proinflammatory effects. For example, collagen is recognized by the leukocyte associated immune receptor (LAIR)-1, which is expressed by most immune cells and induce a state of immunosuppression, but depending on its expression level and interaction with other molecules (e.g., soluble LAIR-2), it may also lead to pathological states $(91,114)$. ECM components were also found to directly influence the activity of HSCs through integrins and discoidin domain-containing receptors (DDRs) $(100,115)$. Moreover, ECM fragments produced during tissue damage, or components actively secreted, can act as DAMPs being recognized by immune system cells through PRRs (91, 116); DAMP-ECM derived responses were found to be mediated primarily by TLR2 and TLR4 (116). ECM components that have been associated with pathological responses include versican (whose mRNA was found to be upregulated in rats with NAFLD, and in biopsies of patients with advanced fibrosis; circulating versican levels were found increased in serum of patients with advanced fibrosis) $(117,118)$, thrombospondin1 (TSP-1; in an in vitro NAFLD model intracellular lipid accumulation was found associated to TSP mRNA upregulation) (119), cysteine-rich protein 61 (CCN1, which induced hepatic inflammation and injury in a mouse model of NAFLD) (120), lumican (whose hepatic expression was found to be high in patients with progressive NAFLD) (121), and periostin (whose circulating and tissue levels were found to be higher in NAFLD patients than controls) $(122,123)$. These ECM components can induce the release of pro-inflammatory cytokines, recruitment and activation of immune cells (91). Other components, on the other hand, have shown anti-inflammatory and anti-fibrotic properties (e.g., Extracellular Matrix Protein-1, ECM1, and High Molecular Weight-Hyaluronic Acid, HMW-HA) (91). Studies have shown a link between their genetic depletion and liver fibrosis progression or their immunosuppressive properties, e.g., through the support of the function of regulatory $\mathrm{T}$ lymphocytes $(91,124,125)$. Moreover, other ECM constituents may have both a pro- or an anti-inflammatory role based on temporal (i.e., stage of the disease) and spatial factors, and depending on the type of receptor or cell from which they are recognized (91). In addition to these effects, ECM is a storage site for cytokines and growth factors (126). 
In case of fibrosis and cirrhosis beyond the quantity, also the composition of the ECM is altered (65). In fact, in a healthy liver, the ECM that surrounds the hepatocytes was found to be formed mainly by type IV collagen, laminins, and proteoglycans, while in a liver with fibrosis fibrillar collagen types I and III become prevalent $(65,127)$. Although in the fibrogenesis process several factors are etiology-independent (127), the progression of fibrosis in chronic liver disease proceeds differently based on the cause. NAFLD, as well as alcoholic steatosis progressing to steatohepatitis, typically has a perisinusoidal (matrix deposition around the sinusoid) and pericellular (around groups of hepatocytes) pattern of fibrogenesis $(65,127)$.

\section{THE IMMUNE SYSTEM IN THE PROGRESSION OF NAFLD}

The immune system plays a key role in hepatic fibrogenesis, as it supports the inflammation that precedes and accompanies the fibrogenic process (128). Recent works have highlighted the link between metabolic dysregulation and activation of the immune system (129-131). As mentioned above, different functions of the immune system are associated with different cellular metabolic activities (e.g., glycolytic vs. oxidative). As hypothesized in a recent review by Cai et al., the altered systemic metabolism that is found in metabolic diseases, characterized by changes in the availability of substrates or presence of specific compounds, could affect the activity of the immune cells by changes in cellular metabolism (132). The recently described trained immunity (TI) or innate immune memory (long lasting, although less than the adaptive immune system memory, increased responsiveness of cells of the innate system, e.g., monocytes, following secondary stimulations with an exogenous or endogenous insult, due to epigenetic changes and not to permanent genetic rearrangements) (133-135), which challenges the historical assumption that the innate system is devoid of memory, was found to be closely interconnected with cellular metabolism (132). Given the important role of the innate system in the pathogenesis of NAFLD, as already proposed (75), TI could be an interesting subject of study in such a disease.

DAMPs and pathogen-associated molecular patterns (PAMPs) are released following NAFLD-associated damage and dysfunctions, they act as a signal of danger and can start an inflammatory process (136). PAMPs are exogenous danger signals made up of various microbially derived molecules, e.g., lipopolysaccharide (LPS), peptidoglycans, bacterial genetic material, etc., which can reach the liver due to the altered intestinal permeability associated with NAFLD (137). DAMPs correspond to endogenous molecules released by damaged cells, which can act as warning signals. DAMPs is a functional definition, and various molecules, with great diversity, are part of this family $(83,136)$, including HSPs, sp100 protein, HMGB1, DNA, RNA, etc. DAMPs and PAMPs are recognized by PRRs, which include TLRs, NOD-like receptors (NLRs), retinoic acid inducible gene I (RIG-I) -like receptors (RLRs), and others $(132,136)$. In this way, they activate cells of the innate immune cells, not purely immune cells, and DAMPs can also regulate adaptive immunity $(138,139)$. TLR4 (receptor for LPS) (55) and TLR9 (DNA) (140) were found implicated in NAFLD progression; TLR5 (flagellin) was hypothesized to have a protective role in liver disease induced by diet (141); TLR2 (cellular components of Gram-positive bacteria) has instead shown contradictory roles (142).

Some lipid species have also been shown that they can directly activate immune cells: saturated fatty acids (SFAs) were observed to induce COX-2 via TLR4 and NFKB in a macrophage-like cell line (143), as well as the activation of inflammatory responses mediated by macrophages and involving the liver was observed following exposure to peroxidized fatty acids (144) and free cholesterol (130, 145). As already mentioned, adipose tissue dysfunction in NAFLD was proposed as another factor inducing hepatic immune system activation, due to the imbalance in cytokine production $(51,137,146)$.

In addition to the innate immunity, which was believed to play a prevalent role, adaptive cells are also greatly involved in NAFLD (147).

As DAMPs can initiate an inflammatory process without the participation of infective agents, they are actors of a sterile inflammation. More precisely, the inflammatory response which occurs in NAFLD is due to metabolic alterations, such as insulin resistance, excess of fat, and lipotoxicity, therefore it can be called "metabolic inflammation." This process is characterized by a chronic low-grade immune activation, which does not resolve (148). This contrasts with an acute insult like microbial infection, in which the immune response is strong, limited in time, and has the purpose of eliminating the pathogen and making the person survive. Prolonged, unresolved, and low-grade inflammation gets no advantage to the host (149), and in NAFLD it causes the onset of scars responsible for liver cirrhosis. Differences in frequency and phenotype of several immune cells were described in NAFLD compared to healthy liver (150). Although the specific role of some of these in NAFLD is far from clear, it is likely that in addition to contributing to inflammation and disease progression, some elements play a protective role, e.g., NK cells through inhibitory cytokines and induction of apoptosis.

\section{Innate Immune System}

The innate immunity is capable of very rapid, although not specific, responses and their subset are important players in the pathogenesis of NASH. As mentioned, non-strictly immune cells, such as hepatocytes, also are included in this field. Innate and innate-like cells predominate in the liver and constitute the first line of defense against danger signals.

\section{Macrophages and Monocytes}

The liver comprises the largest proportion (80-90\%) of resident macrophages in the human body (151). The hepatic macrophages consist of different cell populations including the resident macrophages named Kupffer cells (KC) after their discoverer by Karl Wilhelm von Kupffer (152) and the infiltrating bone marrow derived monocytes $(130,153)$.

The KCs originate from the yolk sac and act as the dominant liver phagocyte. They localize inside the sinusoids directly in contact with blood circulation (154) and can migrate 
through the tissue along sinusoidal walls independently, and in different directions from those of neighboring Kupffer cells (155). The diverse origins of the macrophages reflect the high levels of phenotypical heterogeneity of this cell population $(153,156,157)$. Recent studies, using single-cell RNA sequencing, revealed distinct hepatic macrophages with inflammatory and tolerogenic/non-inflammatory phenotypes $(158,159)$. The different macrophage populations are involved in both hepatic homeostasis and inflammation. KCs promote immune tolerance (160) and play a role in the early response to injury and infection (161), while the infiltrating macrophages are responsible for inflammation and fibrosis progression $(153,162)$.

Through the polarization process, the macrophages differentiate into subpopulations with specific biological functions. Simplifying, they can be divided into M1 macrophages with pro-inflammatory and antimicrobial activity and M2 with anti-inflammatory and reparative functions (153).

Both KCs and infiltrating monocytes play an essential role in various liver diseases. Several reviews have described their role in liver diseases, such as acute liver failure (163), liver fibrosis (164, 165), non-alcoholic fatty liver disease $(130,157,159)$, viral hepatitis (166), and hepatocellular carcinoma (167, 168). Macrophages have been demonstrated to be implicated also in NAFLD development and severity $(130,161)$. In NAFLD subjects the infiltration of portal macrophages is observed at an early stage before the evidence of inflammation and their activation contributes to disease initiation and progression (169). Another study revealed an increase of activated KCs within the hepatic sinusoids in children with NASH (170). In addition, activated KCs modulate the severity of inflammation in NASH (171).

Alternatively, it was described also an anti-inflammatory role for hepatic macrophages; in fact, activated M2 macrophages can favor liver remodeling and tissue repair in NAFLD and initiate the apoptosis of inflammatory KCs (161). Moreover, NAFLD can increase the risk of development of HCC and tumor associated macrophages secrete inflammatory cytokines and growth factors involved in tumor development and progression. Toll-like receptor (TLR) 4 on macrophages has been shown to contribute to HCC proliferation $(167,172)$.

As macrophages play a central role in NAFLD, they might be a suitable target for therapies and a biomarker of diseases severity. In the liver, KCs produce the cytokine TNF- $\alpha$ in response to infections; elevated levels of TNF- $\alpha$ in patients without evidence of NAFLD have been demonstrated to be associated with a high risk of fatty liver development (173). Macrophages produce also other proinflammatory cytokines such as IL1 and IL18. Different studies have proven that IL- $1 \alpha$ and IL- $1 \beta$ have a significant role in the progression of $\operatorname{NAFLD}(174,175)$. Another cytokine potentially applicable in the diagnosis of NAFLD is IL18 , which is produced by macrophages and KCs. Circulating IL18 levels correlate with metabolic syndrome (176), but, on the other hand, it has been also demonstrated that IL-18 production negatively regulates NASH progression via modulation of the gut microbiota (177).

Another cytokine secreted by KCs is TGF- $\beta$; the patients with elevated levels of isoform TGF- $\beta 3$ show a higher risk of NAFLD development (178). Interestingly the soluble macrophage activation marker CD163 has been reported to correlate with liver injury and demonstrated good predictive ability for advanced fibrosis, which was further increased in combination with the NAFLD fibrosis score (179). However, this marker showed poor associations with liver histology in pediatric NAFLD subjects suggesting a possible different role for macrophages in the pathogenesis of adult and pediatric NAFLD (180). Another study demonstrated that the serum macrophagederived deaminase ADA2 activity can predict NAFLD and liver fibrosis (181).

\section{Dendritic Cells}

Dendritic cells (DCs) have been described as interstitial and non-phagocytic cells. They localize periportally, around central veins and in the liver capsule (157). DCs function as antigenpresenting cells (APCs) recruiting other phagocytic cells to the injury site. DCs play an important role to initiate the immune response by capturing, processing, and presenting the antigens to T cells (182). During homeostasis, DCs display a predominant tolerogenic and immature phenotype. While, in the context of inflammatory state, they maturate and enhance the production of proinflammatory cytokines. Mature DCs activate natural killer T cells and promote T-cell proliferation (183). In NASH mice models hepatic DCs exhibit increment of the production of pro-inflammatory cytokines and chemokines (171). Liver DCs are also implicated in adipogenesis, lipid metabolism and synthesis, and hepatic accumulation (184). Human hepatic DCs are composed of two distinct populations that contain different concentrations of lipid, which regulates immunogenic vs. tolerogenic responses. The increased concentration of toxic lipid plays an important role in the pathogenesis of acute and chronic liver diseases $(160,185)$.

\section{Neutrophils}

Neutrophils are the most abundant group of white blood cells circulating in healthy adults and a key component of the innate response. These cells, which have a limited life span (1-2 days), act by phagocytosis, the release of substances (defensins) contained in their granules including neutrophil elastase (NE), myeloperoxidase (MPO), and lysozyme, the production of reactive oxygen species (ROS), and through the NETs (neutrophil extracellular traps) (186). In addition to microbial invasion, metabolic insults can also induce the recruitment and activation of neutrophils (187). In fact, they are part of the inflammatory infiltrate which characterizes the histology of NAFLD (169), and the extent of the infiltration was found to correlate with the severity of the disease (187). They migrate from the blood circulation to the focus of the inflammation, driven by chemokines and chemotactic agents, which are released creating a gradient within the hepatic compartment (188). Neutrophils are among the first cells to invade the liver in NAFLD, and in this site can attract other immune cells $(187,189)$. The invasion begins soon after damage, following the release of DAMPs by the damaged hepatocytes (190); furthermore, danger signals derived from the gut also contribute to the recruitment and activation of neutrophils in NAFLD (191). In NASH it was documented a hepatocyte upregulation of the main chemokines that attract 
neutrophils (186). Neutrophil-to-lymphocyte ratio (NLR) has been observed to correlate with advanced inflammation and fibrosis in NAFLD patients (192). Moreover, NAFLD patients showed an increase in MPO (193), NETs (194), NE, and PR3 (195) circulating levels. The hepatic concentrations of the latter were associated with advanced stages of the disease (195). MPO showed that it could activate HSCs promoting liver fibrogenesis; its pro-fibrogenic role was also linked to the induction of polarization to M2-macrophages $(186,191)$. Furthermore, NE showed to be a regulator of insulin signaling, and its deletion improved insulin sensitivity in a mouse model of obesity (196).

\section{Natural Killer Cells}

Natural killer cells (NK cells) belong to the innate immune system and act through the production of granules containing perforin and granzymes (197), but they can also play an important role in shaping the adaptive immune response (198). In the liver, they are found within the hepatic sinusoids. These cells can be distinguished into CD56 ${ }^{\mathrm{dim}}$ NK cells (which represent the most abundant group in peripheral blood) and CD56 bright (197). NKG2D is an activating receptor expressed by NK cells, but also by others of the immune system such as $\mathrm{T}$ lymphocytes, and is involved in the identification and elimination of damaged cells (199), so acting as a receptor for danger signals. In vitro and in vivo models showed that NK cells can kill human and mouse HSCs by mechanisms dependent on RAE1, NKG2D, TRAIL, NKp46/NCR1, and p38/PI3K (200-202). In a study of NAFLD patients, NASH ones were found to have higher hepatic levels of NK cells and NKG2D mRNA (203). Furthermore, the NK cells showed different levels of activation based on the levels of fibrosis. CD56 ${ }^{\text {dim }}$ NK cells circulating levels were found to be high in advanced fibrosis (F3/F4) than in healthy controls, differently from patients with early stages of the disease; moreover, they were found in an inactive state in patients with NAFLD and advanced fibrosis (204). The increased number observed in advanced disease was hypothesized to be a compensatory event to NK cells impairment. For these reasons, NK cells have been linked to a protective role in liver fibrosis.

\section{Innate-Like, "Unconventional," T Lymphocytes}

Mucosal-Associated Invariant T (MAIT) cells are currently defined as MR1-Ag restricted cells which have a TCR including V $\alpha 7.2$ segment paired with $\mathrm{J} \alpha 33$, J $\alpha 12$, or $\mathrm{J} \alpha 20$; these $\alpha$ chains associate with a limited repertoire of $\beta$-chains. The most studied antigen which MAIT cells recognize by their TCR is a metabolite of riboflavin biosynthesis (205). In healthy people, circulating MAIT cells are $1-10 \%$ of total $\mathrm{T}$ cells, whereas in the liver they reach up to $45 \%$ of intrahepatic $\mathrm{T}$ lymphocytes. They are generally $\mathrm{CD} 3+, \mathrm{DN}$ or $\mathrm{CD} 8+, \mathrm{V} \alpha 7.2+, \mathrm{CD} 161+$, IL-18R $\alpha+$, CD26+, PLZF+ (205). It was observed that in patients with NAFLD related cirrhosis circulating levels of MAIT cells were reduced; in the same study MAIT cells were found to cause proliferation of human hepatic myofibroblasts (HMFs) and release of proinflammatory cytokines by HMFs and macrophages; moreover, CCl4-exposed MAIT cell-deficient mice resulted protected from fibrosis whereas CCl4-exposed
MAIT cell-enriched mice showed an increase in fibrosis (compared with WT ones) (206). Another study showed that circulating MAIT cells were reduced and functionally impaired (decreased production of IFN- $\gamma$ and TNF- $\alpha$ ), in NAFLD patients; MAIT cells were increased in the liver of NAFLD patients, and their number was found to positively correlate with the NAS values (NAFLD activity score); in vitro, activated MAIT cells induced macrophages differentiation toward M2 phenotype, and MAIT cells-deficient MCD-fed mice showed enhanced liver steatosis and inflammation than WT mice, thus suggesting a protective role for these cells in disease progression (207). Given the conflicting results and the limited availability of studies, the role of MAIT cells in NAFLD appears still unclear.

Natural killer T (NKT) cells are CD1d restricted lymphocytes, which recognize lipid antigens. This definition is due to their expression of both the classic T lymphocyte (CD3) and natural killer cell markers (e.g., CD56) (148). These cells can be divided into two subtypes: invariant NKT (iNKT), or NKT type 1 , which possess a semi-invariant TCR- $\alpha$ chain (which in humans includes the V $\alpha 24 / J \alpha 18$ region), and type 2, noninvariant NKT (type 2), with a more variable TCR. They produce cytokines associating with $\mathrm{T}$ helper 1 and $\mathrm{T}$ helper 2 cells, and also utilize Fas and TNF-a to induce apoptosis, guiding the immune system into tolerance or inflammation (208). Regarding the role of NKTs in NAFLD, contradictory data emerged on their effects on hepatic steatosis, inflammation, and fibrosis. In fact, it was observed that in wild-type mice fed with MCD diets, NKT cells had a profibrogenic role by production of osteopontin (OPN) and hedgehog ( $\mathrm{Hh}$ ) ligands, and by activation of HSCs (209). In another study, reduced steatosis, fibrosis, HSCs activation, and hepatic infiltration of inflammatory cells were observed in iNKT cell-deficient mice on CDAA diet (210). However, improvement in NASH associated with an increase in the intrahepatic population of NKT in leptindeficient ob/ob mice model (211), increase in liver fat in CD1d -/ - (lacking NKT cells) mice following HFD (212), and of liver inflammation and fibrosis in iNKT-lacking, HFD-fed mice (193), were also observed.

$\gamma \delta$-T cells express a TCR formed by $\gamma$ and $\delta$ chains (instead of $\alpha$ and $\beta$ ) and are another $\mathrm{T}$ cell population, which can be found in the liver. This group represents $15-25 \%$ of all intrahepatic $\mathrm{T}$ cells (213) and was predominantly found in portal infiltrates and areas of bile duct proliferation or fibrogenesis (214). These cells recognize non-peptide bacterial antigens, and other ligands, and are IL17A producers (215). $\gamma \delta$-T cells were observed to be increased in the liver of HFD-induced obesity and NAFLD mice; reduced liver damage and steatohepatitis were observed in $\gamma \delta \mathrm{T}$ cell-deficient mice. Moreover, the gut microbiota showed to support disease progression by $\gamma \delta$-T IL17+ cells (216). In another study on MCD-fed mice, it was observed that $\gamma \delta$-T depletion protects against steatohepatitis, thus demonstrating their pathogenetic role in NAFLD; in this work, however, the progression of the disease appeared IL-17 independent (217). Further studies are needed to clarify the effect of these cells in the progression of NAFLD. 


\section{Adaptive Immune System}

Adaptive immune cells are recruited by events initiated by innate immunity, but they trigger a more effective, specific response. Although innate immunity has been considered a key player in NAFLD, recent evidence also sheds light on the adaptive system in this condition. After all, NASH is characterized by an intense lymphocytic infiltrate (148), and aggregates of both $\mathrm{T}$ and $\mathrm{B}$ lymphocytes can be found in $\operatorname{NAFLD}(218,219)$.

\section{CD4+ Helper T Lymphocytes}

$\mathrm{CD} 4+\mathrm{T}$ lymphocytes are further divided into subpopulations based on their functions and cytokines production (220). Among these, there are Th1 cells (proinflammatory cells with a critical role in defense against intracellular pathogens, producing IFN$\gamma, \mathrm{IL}-2, \mathrm{TNF} \alpha$ ), Th2 (involved in allergic diseases and response against parasites, producing IL-4, IL-5, IL-13, IL10), Th17 (proinflammatory cells with a defensive role against extracellular bacteria, but also fungi, producing IL17A, IL17F, IL21, IL22, IL23), Th22 (antibacterial functions, producing IL-22), Treg (key elements in the maintenance of self-tolerance, suppressing $\mathrm{T}$ cell activation and releasing IL-10, TGF- $\beta$, IL-4) (220). Liver recruitment of $\mathrm{CD} 4+\mathrm{T}$ lymphocytes was observed in patients and mice models of NASH $(221,222)$. It was observed that methionine and choline-deficient high-fat (MCDHF) fed, IFN$\gamma$-deficient mice showed less steatosis, inflammation, and fibrosis than WT counterparts. In the same study, it was also observed, in vitro, that IFN- $\gamma$ induced TNF- $\alpha$ production by macrophages in a dose-dependent manner (223). Other studies also suggested a role of Th1 in NAFLD, showing an increase of these cells, Th1 proinflammatory cytokines, or genes toward a Th1 phenotype polarization in patients with NASH $(218,224,225)$. In a study of 112 patients with NAFLD (of whom 51 had biopsy-proven NAFL and 30 biopsy-proven NASH) a higher frequency of IFN- $\gamma+$ and/or IL-4+ cells was observed in peripheral blood of patients with NAFL and NASH than healthy controls, and a marked increase in intrahepatic IL-17, IL-4, and IFN- $\gamma$-producing $\mathrm{T}$ cells in NAFLD patients, compared to peripheral blood. In addition, an increase in activation of CD4+ T lymphocytes was documented both in peripheral blood and liver (based on the expression of HLA-DR) (226); Th17 was found to be more abundant in the liver of patients with NASH than in those with NAFL and in circulating blood of NASH patients Th17/Treg ratio was found to be higher than that of NAFL ones. These difference, as well as the histology improved, was found attenuated 1 year after bariatric surgery. Therefore, the authors hypothesized that the balance between Th17 and Treg plays a key role in the pathogenesis of NASH (226). Temporal changes in the frequency of T CD4 lymphocyte populations during NAFLD progression have also been observed: in a study on MCD-fed mice, it was observed an increase in Th17 cells in the first phases of the disease, and in the NASH-fibrosis transition, while Th22 increased between the two Th17 expansions. In the same study, an in vitro model of hepatocyte lipotoxicity documented that IL-17 exacerbated, while IL-22 prevented hepatocyte lipotoxicity (221). The pathogenetic role of IL-17 in progression from NAFL to NASH has also been documented in other studies (227), while the role of IL-22 in chronic liver disease is not so clear (228).
IL-17 has been shown to be able to stimulate Kupffer cells to produce inflammatory and fibrogenic cytokines (including TGF$\beta$ ) and to directly stimulate HSCs by promoting their activation and the production of type 1 collagen by STAT3 (229). For these reasons, as stated in a recent review, Th1 and Th17 lymphocytes are generally attributed a pathogenetic role in the progression of NAFLD (218).

\section{CD8+ Cytotoxic T Lymphocytes}

These effector cells act by releasing cytokines, cytolytic substances such as perforin and granzymes, and cell-cell contact. Cytotoxic $\mathrm{T}$ lymphocytes increase in the liver of people with NAFLD, where they are more activated. Their depletion was observed to be associated with a reduction in steatosis, inflammation, fibrosis, and insulin resistance $(148,220,230)$. Furthermore, CD8 $+\mathrm{T}$ lymphocytes (as well as NKTs) were found to promote the transition from NASH to HCC (231). Their role in the progression of NAFLD, however, needs to be better investigated with further studies.

\section{B Lymphocytes}

B lymphocytes are responsible for various immunological functions, including production of antibodies, antigen presentation, cytokines secretion, and regulation of immune responses. However, their biological function in the liver is still not fully elucidated. Only a small number of B cells are residing in the healthy liver and, maybe since hepatic $B$ cells comprise only $\sim 5 \%$ of intrahepatic lymphocytes, there are experimental difficulties in isolating and analyzing specifically these cells (232). This lymphocytes population has been shown to infiltrate the liver parenchyma of NASH patients. These cells may contribute to the progression of the disease through the production of inflammatory mediators and antigen presentation (218); they showed to exert a profibrogenic role through the release of inflammatory cytokines stimulating HSCs (233). In mouse models of NAFLD, it was observed that B lymphocytes were activated early in the course of the disease and resulted important for recruitment and activation of $\mathrm{T}$ lymphocytes (219). Circulating levels of the cytokine BAFF were found to be higher in patients with NASH than in those with simple steatosis, and the higher levels of this cytokine correlated with hepatocyte ballooning and advanced fibrosis (234). In a study in which biopsy-proven NAFL and NASH patients had serum immunoglobulin measurements, it was also observed that $\operatorname{IgA}$ levels were elevated more frequently in NASH patients compared to those with simple steatosis (235).

\section{THERAPEUTIC APPROACHES ACTING ON THE IMMUNE SYSTEM TO COUNTER THE PROGRESSION OF NAFLD}

Several drugs have been studied to reduce liver inflammation and fibrogenesis in NAFLD, resolution of steatohepatitis and improvement in liver fibrosis representing two key endpoints of current trials (236). Moreover, it is also being studied the effect of the combination of molecules acting on different targets. However, despite the advances in knowledge of the fibrogenic 
process leading to cirrhosis, to date there are no approved and specific pharmacotherapy to resolve NASH, and targeting the predisposing factors (by lifestyle modifications and weight loss) is considered the best therapeutic option (237). The regression of fibrosis is already obtainable in some conditions, such as in chronic viral hepatitis after antiviral therapy, or for obese NAFLD patients, following bariatric surgery $(65,238)$. Given the key role of the immune system in the progression of NAFLD, therapeutic approaches aimed at counteracting its harmful role in pathogenesis have also been tested (239). Although many extensively examined or new molecules under study for NAFLD not acting directly on the immune system cells, for example having a primary antioxidant effect (e.g., vitamin E) (240), acting on bile acid metabolism [e.g., OCA, which is the most advanced molecule in the race for drug approval to treat NASH (236)] or on glucose or lipid metabolism (e.g., Elafibranor), or having other primary targets, spill over their action to the immune system (86), below they will be summarized only approaches directly engaging the immune substrate of NAFLD (a list is provided in Table $\mathbf{1}$ ).

Cenicriviroc (CVC) is a C-C chemokine receptor type 2 and 5 (CCR2 and CCR5) antagonist, expressed mainly on monocytes the former, and on various immune system cells (including lymphocytes) and HSCs the latter. Following the recognition of their ligands, these receptors participate in the recruitment and activation of various immune cells, which were linked to amplification and perpetuation of the inflammatory response in NAFLD (241). Therefore, the rationale for the use of CVC was a reduced migration and hepatic infiltration of monocytes/macrophages (due to the blockade of CCR2), and a reduced migration and activation of HSCs (due to the parallel inhibition of CCR5). Preclinical studies have shown its effectiveness in reducing liver fibrosis (241). In a study (CENTAUR trial) involving 289 subjects with NASH and hepatic fibrosis in which 145 received CVC and 144 placebo, it was observed that it was safe and welltolerated, but the primary outcome of improvement in NAS by $\geq 2$ points without worsening of fibrosis after 1 year, was not met. However, this drug improved liver fibrosis in a significantly higher percentage of cases than placebo (20 vs. 10\%) (242). After 2 years of treatment, most people who achieved improvement in fibrosis maintained this result (243). It was being tested in a randomized, double-blind, placebo-controlled phase 3 trial (AURORA) to evaluate its efficacy in the treatment of liver fibrosis in adults with NASH (244), but this study was stopped early due to lack of efficacy (245).

Galectin inhibitors are a class of compounds that interfere with galectins. The latter are carbohydrate-binding proteins that are located inside the cells, in the cytoplasm, in states of quiescence, but can be externalized. In fact, in case of tissue damage, the cytosolic galectins are actively secreted by the cells, and act as DAMP. The main galectin produced during damage is Galectin-3 (Gal-3), which is primarily produced by macrophages (246). It is involved in several inflammatory processes, including the adhesion of neutrophils, opsonization, and macrophages chemoattraction $(247,248)$. Moreover, Gal-3 was found to lead to myofibroblast activation (249), and was linked to the fibrogenesis process in different liver diseases (246). Galectin-3 inhibitors resulted effective in preclinical studies of NASH and liver fibrosis (250). Among the galectin inhibitors, there is belapectin (GRMD-02), a natural plant derived molecule that binds to Gal3 (but also to galectin-1). In a phase 1 study, GR-MD-02 was shown to be safe and well-tolerated in patients with NASH or advanced fibrosis proven by biopsy (251). Therefore, its efficacy was studied in a randomized placebo-controlled trial in patients with liver cirrhosis and portal hypertension; 162 participants were randomized to receive belapectin, 2 or $8 \mathrm{mg} / \mathrm{kg}$, or placebo, but neither dose was found to reach the primary endpoint (HVPG reduction), nor improve liver fibrosis, or reduce the incidence of complications of cirrhosis. However, this drug showed to be associated with an improvement in hepatocyte ballooning. It was also observed that belapectin could have a favorable effect on HVPG and the development of varices in a specific group of patients (NASH-cirrhosis without varices at baseline) (246). A study to evaluate the safety and efficacy of belapectin vs. placebo for the prevention of esophageal varices in patients affected by NASH cirrhosis with signs of portal hypertension but without esophageal varices (NAVIGATE) is currently ongoing (252).

Hepatic macrophages are an interesting target for novel therapeutic approaches for liver diseases. However, there are some important challenges to be faced, like the quite opposing functions of macrophage subsets depending on the experimental condition observed in the animal models, the not complete comparability between animal and human diseases, and the complex human macrophages heterogeneity. However, the increasing understanding about macrophages allowed the identification of several pathways that regulate their recruitment, differentiation/polarization and activation, offering promising starting points for novel therapeutic intervention. Different approaches include inhibition of KCs activation, dampening of monocyte recruitment into the liver, and modulation of macrophage polarization/differentiation. KCs activation can be influenced by several approaches. Using antibiotics, it is possible to reduce the bacterial infection and the consequent TLR4dependent macrophage activation, ameliorating steatohepatitis, fibrosis, and hepatocarcinogenesis in mice models $(253,254)$. Antibiotics act influencing the gut barrier and microbiota. Also the probiotics could potentially alleviate pathogenic Kupffer cell activation in the liver (255). Probiotics have several beneficial properties, including interaction with the enterohepatic axis. It has been shown that the use of preparations containing different strains of bacteria and a probiotic in patients with NAFLD is associated with a significant reduction of hs-CRP, TNF- $\alpha$, and TNFK-B p65 (256). Beneficial effects of other multiprobiotic compounds have been observed in patients with NAFLD (257). Inflammatory monocytes recruitment to the liver is driven by chemokines. Therefore, different pharmacological strategies have been generated to interfere with chemokine signaling, including monoclonal antibodies, receptor antagonists, inhibition of chemokines (258); an example of this type of pharmacological approach is the aforementioned cenicriviroc. KCs have a high scavenging capacity, which can be used for drug delivery. In fact, dexamethasone has 
TABLE 1 | Summary of the drugs recently studied for NAFLD therapy which have a mechanism of action that involves immune system modulation.

\begin{tabular}{|c|c|c|c|c|c|c|c|}
\hline $\begin{array}{l}\text { Drug name (study } \\
\text { reference) }\end{array}$ & Drug type & Mechanism of action & Expected effect & Administration route & $\begin{array}{l}\text { Experimental stage } \\
\text { reached }\end{array}$ & Efficacy & Future perspectives \\
\hline Cenicriviroc (245) & $\begin{array}{l}\text { C-C chemokine } \\
\text { receptor type } 2 \text { and } 5 \\
\text { antagonist }\end{array}$ & $\begin{array}{l}\text { Reduction of migration of } \\
\text { monocytes/macrophages, } \\
\text { reduction of HSCs } \\
\text { activation }\end{array}$ & $\begin{array}{l}\text { Antinflammatory, } \\
\text { antifibrotic }\end{array}$ & Daily oral route & $\begin{array}{l}\text { Phase-3 double blind } \\
\text { RCT }\end{array}$ & Stopped for lack of efficacy & $\begin{array}{l}\text { Not approved in } \\
\text { monotherapy, } \\
\text { association with } \\
\text { Tropifexor ongoing }\end{array}$ \\
\hline $\begin{array}{l}\text { Belapectin (GR-MD-02) } \\
\text { (252) }\end{array}$ & Galectin inhibitor & $\begin{array}{l}\text { Reduction of galectin } \\
\text { secretion with reduction of } \\
\text { neutrophils adhesion, } \\
\text { opsonization, } \\
\text { macrophage } \\
\text { chemoattraction, } \\
\text { myofibroblast activation }\end{array}$ & $\begin{array}{l}\text { Antinflammatory, } \\
\text { antifibrotic, portal } \\
\text { hypertension reduction }\end{array}$ & Intravenously & $\begin{array}{l}\text { Phase-2b double blind } \\
\text { RCT }\end{array}$ & $\begin{array}{l}\text { Only efficacious in reducing } \\
\text { HVPG in pts without } \\
\text { esophageal varices at } \\
\text { baseline }\end{array}$ & $\begin{array}{l}\text { Phase } 2 \mathrm{~b} / 3 \text { trial on the } \\
\text { efficacy on preventing } \\
\text { varices in NASH } \\
\text { cirrhosis pts without } \\
\text { varices ongoing }\end{array}$ \\
\hline Protexin capsules (256) & $\begin{array}{l}\text { Synbiotic supplement } \\
\text { (prebiotic and probiotic) }\end{array}$ & $\begin{array}{l}\text { Attenuation of } \\
\text { inflammatory responses }\end{array}$ & $\begin{array}{l}\text { Antinflammatory, } \\
\text { antifibrotic }\end{array}$ & Daily oral route & Double blind RCT & $\begin{array}{l}\text { Improved liver biochemistry, } \\
\text { reduced transient } \\
\text { elastography score }\end{array}$ & $\begin{array}{l}\text { Available for clinical } \\
\text { use, effects of longer } \\
\text { treatment durations } \\
\text { remain to be } \\
\text { determined }\end{array}$ \\
\hline Symbiter (257) & Multi-probiotic & $\begin{array}{l}\text { Reduction of the } \\
\text { inflammatory response } \\
\text { and hepatic triglycerides } \\
\text { content }\end{array}$ & $\begin{array}{l}\text { Antisteatosic, } \\
\text { antinflammatory, } \\
\text { antifibrotic }\end{array}$ & Daily oral route & Double blind RCT & $\begin{array}{l}\text { Reduced liver fat, AST, GGT, } \\
\text { TNF- } \alpha \text {, and IL-6 in NAFLD } \\
\text { patients }\end{array}$ & $\begin{array}{l}\text { Available for clinical } \\
\text { use, long-term studies } \\
\text { required }\end{array}$ \\
\hline JKB-121 (264) & TLR-4 antagonist & $\begin{array}{l}\text { Reduction of TLR-4 } \\
\text { mediated liver } \\
\text { inflammation and fibrosis }\end{array}$ & $\begin{array}{l}\text { Antinflammatory, } \\
\text { antifibrotic }\end{array}$ & Twice daily & Phase $2 \mathrm{~b}$ RCT & $\begin{array}{l}\text { JKB-121 did not perform } \\
\text { better than placebo in } \\
\text { improving liver fat content } \\
\text { and/or serum ALT in NASH } \\
\text { patients }\end{array}$ & $\begin{array}{l}\text { Further studies on the } \\
\text { inhibition of TLR-4 are } \\
\text { needed }\end{array}$ \\
\hline GPR84 Antagonist (266) & GPR84 antagonist & $\begin{array}{l}\text { Inhibition of inflammatory } \\
\text { responses GPR84 } \\
\text { mediated }\end{array}$ & $\begin{array}{l}\text { Antinflammatory, } \\
\text { antifibrotic }\end{array}$ & Orally administered & $\begin{array}{l}\text { Preclinical (mouse) } \\
\text { NAFLD model }\end{array}$ & $\begin{array}{l}\text { Reduced macrophages and } \\
\text { neutrophil infiltration, } \\
\text { ameliorated steatohepatitis }\end{array}$ & Further studies needed \\
\hline BI 1467335 (271) & VAP-1 inhibitor & $\begin{array}{l}\text { Reduction of hepatic } \\
\text { accumulation of } \\
\text { inflammatory cells }\end{array}$ & $\begin{array}{l}\text { Antinflammatory, } \\
\text { antifibrotic }\end{array}$ & Oral tablets & Phase 2 RCT & Improved NASH biomarkers & $\begin{array}{l}\text { Development } \\
\text { discontinued (risk of } \\
\text { drug interactions) }\end{array}$ \\
\hline Sandy-2 (219) & $\begin{array}{l}\text { B-cell Activating Factor } \\
\text { (BAFF) -neutralizing } \\
\text { monoclonal antibody }\end{array}$ & $\begin{array}{l}\text { Prevention of } \mathrm{B} \text { cells } \\
\text { maturation }\end{array}$ & $\begin{array}{l}\text { Antinflammatory, } \\
\text { antifibrotic }\end{array}$ & I.p. injection & $\begin{array}{l}\text { Preclinical (mouse) } \\
\text { NASH model }\end{array}$ & $\begin{array}{l}\text { Prevented hepatic B cell } \\
\text { maturation, reduced Th-1 } \\
\text { lymphocytes activation, } \\
\text { ameliorated steatohepatitis }\end{array}$ & Further studies needed \\
\hline OKT3 Mab (274) & $\begin{array}{l}\text { Anti-CD3 monoclonal } \\
\text { antibody }\end{array}$ & $\begin{array}{l}\text { Immunomodulatory effect, } \\
\text { induction of regulatory T } \\
\text { cells (Tregs) }\end{array}$ & $\begin{array}{l}\text { Antinflammatory, } \\
\text { antifibrotic }\end{array}$ & Oral once daily & Phase 2a RCT & $\begin{array}{l}\text { Improved liver, metabolic, } \\
\text { and immunologic } \\
\text { parameters }\end{array}$ & $\begin{array}{l}\text { Further trials are } \\
\text { needed }\end{array}$ \\
\hline
\end{tabular}


been demonstrated to reduce fibrosis in mice models through a macrophage-targeted delivery $(259,260)$. A fascinating alternative to treat liver disease in a murine model is the infusion of KCs expanded in vitro to ameliorate liver fibrosis (261). Moreover, macrophages can be isolated from apheresis derived CD14 monocytes of cirrhotic patients and differentiated into macrophages with a pro-resolution phenotype (262, 263).

JKB-121 is an antagonist of TLR-4, which was linked to liver inflammation and fibrosis. Encouraging results derived from preclinical studies on the antagonism of TLR4, but, in a trial on patients with biopsy-proven NASH, grade 1-3 fibrosis, and hypertransaminasemia JKB-121 did not reach the endpoint of reducing the liver fat content by MRI-PDFF and/or serum ALT after 24 weeks (264).

GRI0621, a natural killer T (NKT) cells antagonist, has been investigated in a study on patients with chronic liver disease including NASH to test its effects, but the study was discontinued for administrative decision (265).

G protein-coupled receptor 84 (GPR84) is a surface receptor for medium-chain fatty acids (MCFA). This receptor is expressed by several cells of the innate immune system and showed proinflammatory functions (266). In GPR84-deficient mice, LCFA diet did not cause an increase in liver mass as was observed in WT counterparts (267). In a recent study, it was observed that GPR84 expression was increased in the liver of mice and humans with NAFLD and was associated with inflammation and fibrosis; GPR84 antagonists were found to reduce chemotaxis of monocytes and neutrophils. Moreover, these molecules showed to reduce macrophages accumulation and to improve inflammation and fibrosis in mouse models of NASH. The therapeutic effects in ameliorating steatohepatitis and fibrosis of GPR84 antagonists were linked to the inhibition of the migration of myeloid cells, and not to effects on HSCs, which were not found to express GPR84 (266). Further studies are needed to validate the effectiveness of targeting this system.

Vascular adhesion protein-1 (VAP-1) is a glycoprotein, which has amine oxidase activity and is involved in endothelial adhesion and transmigration processes of leukocytes (268). There is also a soluble form of VAP-1 (sVAP-1), whose levels were found to be elevated in patients with cardiovascular, metabolic (e.g., diabetes and obesity) and hepatic diseases (269). In the liver, it was found involved in the adhesion and transendothelial migration (through the sinusoids) of lymphocytes. It has been observed that sVAP-1 is increased in NAFLD patients and that VAP-1 hepatic expression is increased in patients affected by steatohepatitis compared to those with simple steatosis (269). Moreover, in mouse models of liver damage, inhibition of VAP1 (by VAP-1-deficient mice or VAP-1 neutralizing antibodies) reduced hepatic migration of inflammatory cells ( $\mathrm{T}$ cells, NKT cells, and myeloid cells) and attenuated fibrosis (269). Results of another study suggested that VAP-1 may contribute to the progression of NAFLD (270). Hence it has been proposed as a target to limit the progression of NAFLD. A phase II trial was started to document the effects of inhibiting VAP-1 (BI 1467335) in patients with NASH (271); however, the research company announced that it has stopped developing this molecule in NASH due to the risk of drug interactions ${ }^{1}$.

The role of B lymphocytes in the progression of NAFLD has been documented (218). Furthermore, the cytokine Bcell Activating Factor (BAFF), necessary for survival and maturation of B lymphocytes, has also been studied in patients with NAFLD. Circulating BAFF levels were found to be higher in patients with steatohepatitis than in those with NAFL (234). BAFF neutralization through BAFF-neutralizing monoclonal antibody Sandy-2 was shown to improve steatosis, inflammation, and fibrosis in transgenic (NASH model) mice overexpressing a soluble form of a BAFF/APRIL receptor (TACIIg) (219).

CD3 molecule is associated with the TCR receptor, and this complex is found on the surface of $\mathrm{T}$ lymphocytes. Unlike TCR, CD3 is not variable. Muromonab (OKT3) has been the first approved monoclonal antibody and was used to treat organ transplant rejection, but its application is limited by high toxicity. Hence, humanized anti-CD3 antibodies were developed to improve tolerability (272). In a preclinical study on ob/ob mice, anti-CD3 $\mathrm{mAb}$ showed to reduce liver fat, adipose tissue inflammation, and blood glucose (273). OKT3 was tested at different dosages $(0.2,1.0,5.0 \mathrm{mg} /$ day $)$ in a phase II trial in patients with biopsy-proven NASH to determine its effects. This drug, administered for 30 days, was well-tolerated and led to the induction of regulatory $\mathrm{T}$ lymphocytes (274).

\section{CONCLUSIONS}

Inflammation and fibrogenesis in NAFLD are multifactorial processes involving a multitude of interrelated mechanisms, and in which the immune system plays a key role. Although challenges about its pathogenesis still exist, the knowledge on NAFLD is increasing, leading, also for this reason, to the recent proposal of rename. Therapies aimed at directly fighting the immune substrate of NAFLD are already being studied. In any case, the precise characterization of some elements of the immune system has only occurred in recent years, and the specific role of many subsets in the pathogenesis of NAFLD, as well as that of many other human diseases, is still far from clear. Furthermore, the relationship between cellular metabolism and immune cell functions, termed "immunometabolism," is a candidate for future studies in the field of NAFLD. This knowledge could allow scientists to further elucidate the pathophysiology of this complex disease and to hypothesize new therapeutic approaches.

\section{AUTHOR CONTRIBUTIONS}

PT and BMM wrote the paper. All authors participated in revising the manuscript.

${ }^{1}$ Available online at: https://www.boehringer-ingelheim.us/press-release/ boehringer-ingelheim-discontinues-development-bi-1467335-nash. 


\section{REFERENCES}

1. Eslam M, Sanyal AJ, George J. MAFLD: a consensus-driven proposed nomenclature for metabolic associated fatty liver disease. Gastroenterology. (2020) 158:1999-2014.e1. doi: 10.1053/j.gastro.2019.11.312

2. Ludwig J, Viggiano TR, McGill DB, Oh BJ. Nonalcoholic steatohepatitis: Mayo Clinic experiences with a hitherto unnamed disease. Mayo Clin Proc. (1980) 55:434-8.

3. Schaffner F, Thaler H. Nonalcoholic fatty liver disease. Prog Liver Dis. (1986) 8:283-98.

4. European Association for the Study of the Liver (EASL). EASL-EASD-EASO Clinical Practice Guidelines for the management of non-alcoholic fatty liver disease. J Hepatol. (2016) 64:1388-402. doi: 10.1016/j.jhep.2015.11.004

5. Chalasani N, Younossi Z, Lavine JE, Charlton M, Cusi K, Rinella M, et al. The diagnosis and management of nonalcoholic fatty liver disease: Practice guidance from the American Association for the Study of Liver Diseases. Hepatology. (2018) 67:328-57. doi: 10.1002/hep.29367

6. Ando Y, Jou JH. Nonalcoholic fatty liver disease and recent guideline updates. Clinical Liver Disease. (2021) 17:23-28. doi: 10.1002/cld.1045

7. Eslam M, Sarin SK, Wong V, Fan J-G, Kawaguchi T, Ahn SH, et al. The Asian Pacific Association for the Study of the Liver clinical practice guidelines for the diagnosis and management of metabolic associated fatty liver disease. Hepatol Int. (2020) 14:889-919. doi: 10.1007/s12072-020-10094-2

8. Chakravarthy MV, Neuschwander-Tetri BA. The metabolic basis of nonalcoholic steatohepatitis. Endocrinol Diabetes Metab. (2020) 3:e00112. doi: 10.1002/edm2.112

9. Bellentani S, Tiribelli C. Is it time to change NAFLD and NASH nomenclature? Lancet Gastroenterol Hepatol. (2017) 2:547-8. doi: 10.1016/S2468-1253(17)30146-2

10. Younossi ZM, Rinella ME, Sanyal AJ, Harrison SA, Brunt EM, Goodman $Z$, et al. From NAFLD to MAFLD: implications of a premature change in terminology. Hepatology. (2021) 73:1194-8. doi: 10.1002/hep.31420

11. Godoy-Matos AF, Silva Júnior WS, Valerio CM. NAFLD as a continuum: from obesity to metabolic syndrome and diabetes. Diabetol Metab Syndr. (2020) 12:60. doi: 10.1186/s13098-020-00570-y

12. Younossi ZM, Koenig AB, Abdelatif D, Fazel Y, Henry L, Wymer M. Global epidemiology of nonalcoholic fatty liver disease-Meta-analytic assessment of prevalence, incidence, and outcomes. Hepatology. (2016) 64:73-84. doi: $10.1002 /$ hep. 28431

13. Allen AM, Therneau TM, Larson JJ, Coward A, Somers VK, Kamath PS. Nonalcoholic fatty liver disease incidence and impact on metabolic burden and death: A 20 year-community study. Hepatology. (2018) 67:1726-36. doi: 10.1002/hep.29546

14. Liangpunsakul S, Chalasani N. Unexplained elevations in alanine aminotransferase in individuals with the metabolic syndrome: results from the third national health and nutrition survey (NHANES III). Am J Med Sci. (2005) 329:111-6. doi: 10.1097/00000441-200503000-00001

15. Ma J, Hwang S-J, Pedley A, Massaro JM, Hoffmann U, Chung RT, et al. Bi-directional analysis between fatty liver and cardiovascular disease risk factors. J Hepatol. (2017) 66:390-7. doi: 10.1016/j.jhep.2016.09.022

16. Targher G, Day CP, Bonora E. Risk of cardiovascular disease in patients with nonalcoholic fatty liver disease. N Engl J Med. (2010) 363:1341-50. doi: 10.1056/NEJMra0912063

17. Oni ET, Agatston AS, Blaha MJ, Fialkow J, Cury R, Sposito A, et al. A systematic review: Burden and severity of subclinical cardiovascular disease among those with nonalcoholic fatty liver; Should we care? Atherosclerosis. (2013) 230:258-67. doi: 10.1016/j.atherosclerosis.2013.07.052

18. Schulze RJ, Schott MB, Casey CA, Tuma PL, McNiven MA. The cell biology of the hepatocyte: A membrane trafficking machine. J Cell Biol. (2019) 218:2096-112. doi: 10.1083/jcb.201903090

19. Lian ZX, Li L. The Liver as a Lymphoid Organ, in Liver Immunology: Principles and Practice, Gershwin ME, et al. Editors. 2020. Cham: Springer International Publishing (2020). doi: 10.1007/978-3-030-51709-0_2

20. Kim HM, Park BS, Kim J-I, Kim SE, Lee J, Oh SC, et al. Crystal structure of the TLR4-MD-2 complex with bound endotoxin antagonist eritoran. Cell. (2007) 130:906-17. doi: 10.1016/j.cell.2007.08.002

21. Zhou Z, Xu M-J, Gao B. Hepatocytes: a key cell type for innate immunity. Cell Mol Immunol. (2016) 13:301-15. doi: 10.1038/cmi.2015.97
22. Kubes P, Jenne C. Immune responses in the liver. Annu Rev Immunol. (2018) 36:247-77. doi: 10.1146/annurev-immunol-051116-052415

23. Schildberg FA, Hegenbarth SI, Schumak B, Scholz K, Limmer A, Knolle PA. Liver sinusoidal endothelial cells veto CD8 T cell activation by antigen-presenting dendritic cells. Eur J Immunol. (2008) 38:957-67. doi: $10.1002 /$ eji.200738060

24. Diehl L, Schurich A, Grochtmann R, Hegenbarth S, Chen L, Knolle PA. Tolerogenic maturation of liver sinusoidal endothelial cells promotes B7homolog 1-dependent CD8+ T cell tolerance. Hepatology. (2008) 47:296305. doi: 10.1002/hep. 21965

25. Limmer A, Ohl J, Kurts C, Ljunggren H-G, Reiss Y, Groettrup M, et al. Efficient presentation of exogenous antigen by liver endothelial cells to CD8+ T cells results in antigen-specific T-cell tolerance. Nat Med. (2000) 6:1348-54. doi: 10.1038/82161

26. Crispe IN, Giannandrea M, Klein I, John B, Sampson B, Wuensch S. Cellular and molecular mechanisms of liver tolerance. Immunol Rev. (2006) 213:10118. doi: 10.1111/j.1600-065X.2006.00435.x

27. Shetty S, Lalor PF, Adams DH. Liver sinusoidal endothelial cells - gatekeepers of hepatic immunity. Nat Rev Gastroenterol Hepatol. (2018) 15:555-67. doi: 10.1038/s41575-018-0020-y

28. Carambia A, Freund B, Schwinge D, Heine M, Laschtowitz A, Huber S, et al. TGF- $\beta$-dependent induction of CD4?CD25?Foxp3? Tregs by liver sinusoidal endothelial cells. J Hepatol. (2014) 61:594-9. doi: 10.1016/j.jhep.2014.04.027

29. Harada K, Isse K, Sato Y, Ozaki S, Nakanuma Y. Endotoxin tolerance in human intrahepatic biliary epithelial cells is induced by upregulation of IRAK-M. Liver Int. (2006) 26:935-42. doi: 10.1111/j.1478-3231.2006.01325.x

30. Schildberg FA, Wojtalla A, Siegmund SV, Endl E, Diehl L, Abdullah Z, et al. Murine hepatic stellate cells veto CD8 $\mathrm{T}$ cell activation by a CD54-dependent mechanism. Hepatology. (2011) 54:262-72. doi: 10.1002/hep.24352

31. Kurioka A, Walker LJ, Klenerman P, Willberg CB. MAIT cells: new guardians of the liver. Clin Transl Immunology. (2016) 5:e98. doi: 10.1038/cti.2016.51

32. Horst AK, Neumann K, Diehl L, Tiegs G. Modulation of liver tolerance by conventional and nonconventional antigen-presenting cells and regulatory immune cells. Cell Mol Immunol. (2016) 13:277-92. doi: $10.1038 / \mathrm{cmi} .2015 .112$

33. Zheng M, Tian Z. Liver-mediated adaptive immune tolerance. Front Immunol. (2019) 10:2525. doi: 10.3389/fimmu.2019.02525

34. Calne RY, Sells RA, Pena JR, Davis DR, Millard PR, Herbertson BM, et al. Induction of immunological tolerance by porcine liver allografts. Nature. (1969) 223:472-6. doi: 10.1038/223472a0

35. Van Rood JJ, Van Leeuwen A, Van Santen MCT. Anti HL-A2 Inhibitor in Normal Human Serum. Nature. (1970) 226:366-7. doi: 10.1038/226366a0

36. Benseler V, McCaughan GW, Schlitt HJ, Bishop GA, Bowen DG, Bertolino P. The liver: a special case in transplantation tolerance. Semin Liver Dis. (2007) 27:194-213. doi: 10.1055/s-2007-979471

37. Crispe IN. The liver as a lymphoid organ. Ann Rev Immunol. (2009) 27:14763. doi: 10.1146/annurev.immunol.021908.132629

38. Uchikura K, Wada T, Hoshino S, Nagakawa Y, Aiko T, Bulkley GB, et al. Lipopolysaccharides induced increases in Fas ligand expression by Kupffer cells via mechanisms dependent on reactive oxygen species. Am J Physiol Gastrointest Liver Physiol. (2004) 287:G620-6. doi: 10.1152/ajpgi.003 14.2003

39. Crispe IN, Dao T, Klugewitz K, Mehal WZ, Metz DP. The liver as a site of T-cell apoptosis: graveyard, or killing field? Immunol Rev. (2000) 174:47-62. doi: $10.1034 /$ j.1600-0528.2002.017412.x

40. Li F, Tian Z. The liver works as a school to educate regulatory immune cells. Cell Mol Immunol. (2013) 10:292-302. doi: 10.1038/cmi.2013.7

41. Yu J, Chen $\mathrm{Y}, \mathrm{Wu} \mathrm{Y}$, Ye L, Lian Z, Wei H, et al. The differential organogenesis and functionality of two liver-draining lymph nodes in mice. J Autoimmunity. (2017) 84:109-21. doi: 10.1016/j.jaut.2017. 08.005

42. Fiorucci S, Biagioli M, Zampella A, Distrutti E. Bile acids activated receptors regulate innate immunity. Front Immunol. (2018) 9:1853. doi: $10.3389 /$ fimmu.2018.01853

43. Mencarelli A, Renga B, Migliorati M, Cipriani S, Distrutti E, Santucci L, et al. The bile acid sensor Farnesoid $\mathrm{x}$ receptor is a modulator of liver immunity in a rodent model of acute hepatitis. J Immunol. (2009) 183:6657-66. doi: 10.4049/jimmunol.0901347 
44. O’Neill LA, Kishton RJ, Rathmell J. A guide to immunometabolism for immunologists. Nat Rev Immunol. (2016) 16:553-65. doi: $10.1038 /$ nri. 2016.70

45. Michalek RD, Gerriets VA, Jacobs SR, Macintyre AN, MacIver NJ, Mason EF, et al. Cutting edge: distinct glycolytic and lipid oxidative metabolic programs are essential for effector and regulatory CD4+ T cell subsets. J Immunol. (2011) 186:3299-303. doi: 10.4049/jimmunol.1003613

46. Cramer T, Yamanishi Y, Clausen BE, Förster I, Pawlinski R, Mackman N, et al. HIF-1alpha is essential for myeloid cell-mediated inflammation. Cell. (2003) 112:645-57. doi: 10.1016/S0092-8674(03)00154-5

47. Vats D, Mukundan L, Odegaard JI, Zhang L, Smith KL, Morel CR, et al. Oxidative metabolism and PGC-1beta attenuate macrophage-mediated inflammation. Cell Metab. (2006) 4:13-24. doi: 10.1016/j.cmet.2006.05.011

48. Jung J, Zeng H, Horng T. Metabolism as a guiding force for immunity. Nat Cell Biol. (2019) 21:85-93. doi: 10.1038/s41556-018-0217-x

49. Day CP, James OF. Steatohepatitis: a tale of two "hits"? Gastroenterology. (1998) 114:842-5. doi: 10.1016/S0016-5085(98)70599-2

50. Tilg H, Moschen AR. Evolution of inflammation in nonalcoholic fatty liver disease: the multiple parallel hits hypothesis. Hepatology. (2010) 52:1836-46. doi: 10.1002/hep. 24001

51. Buzzetti E, Pinzani M, Tsochatzis EA. The multiple-hit pathogenesis of non-alcoholic fatty liver disease (NAFLD). Metabolism. (2016) 65:1038-48. doi: 10.1016/j.metabol.2015.12.012

52. Miele L, Valenza V, La Torre G, Montalto M, Cammarota G, Ricci $\mathrm{R}$, et al. Increased intestinal permeability and tight junction alterations in nonalcoholic fatty liver disease. Hepatology. (2009) 49:1877-87. doi: 10.1002/hep. 22848

53. Boursier J, Mueller O, Barret M, Machado M, Fizanne L, Araujo-Perez F, et al. The severity of nonalcoholic fatty liver disease is associated with gut dysbiosis and shift in the metabolic function of the gut microbiota. Hepatology. (2016) 63:764-75. doi: 10.1002/hep.28356

54. Kapil S, Duseja A, Sharma BK, Singla B, Chakraborti A, Das A, et al. Small intestinal bacterial overgrowth and toll-like receptor signaling in patients with non-alcoholic fatty liver disease. J Gastroenterol Hepatol. (2016) 31:21321. doi: 10.1111 /jgh. 13058

55. Rivera CA, Adegboyega P, van Rooijen N, Tagalicud A, Allman M, Wallace M. Toll-like receptor- 4 signaling and Kupffer cells play pivotal roles in the pathogenesis of non-alcoholic steatohepatitis. J Hepatol. (2007) 47:571-9. doi: 10.1016/j.jhep.2007.04.019

56. Mancina RM, Dongiovanni P, Petta S, Pingitore P, Meroni M, Rametta R, et al. The MBOAT7-TMC4 variant rs641738 increases risk of nonalcoholic fatty liver disease in individuals of European descent. Gastroenterology. (2016) 150:1219-30.e6. doi: 10.1053/j.gastro.2016.01.032

57. Eslam M, Valenti L, Romeo S. Genetics and epigenetics of NAFLD and NASH: Clinical impact. J Hepatol. (2018) 68:268-79. doi: 10.1016/j.jhep.2017.09.003

58. Jonas W, Schürmann A. Genetic and epigenetic factors determining NAFLD risk. Mol Metab. (2021) 50:101111. doi: 10.1016/j.molmet.2020.101111

59. Pirola CJ, Fernández Gianotti T, Castaño GO, Mallardi P, San Martino J, Mora Gonzalez Lopez Ledesma $\mathrm{M}$, et al. Circulating microRNA signature in non-alcoholic fatty liver disease: from serum non-coding RNAs to liver histology and disease pathogenesis. Gut. (2015) 64:800-12. doi: 10.1136/gutjnl-2014-306996

60. Murphy SK, Yang H, Moylan CA, Pang H, Dellinger A, Abdelmalek MF, et al. Relationship between methylome and transcriptome in patients with nonalcoholic fatty liver disease. Gastroenterology. (2013) 145:1076-87. doi: 10.1053/j.gastro.2013.07.047

61. Federico A, Rosato V, Masarone M, Torre P, Dallio M, Romeo M, et al. The role of fructose in non-alcoholic steatohepatitis: old relationship and new insights. Nutrients. (2021) 13:1314. doi: 10.3390/nu13041314

62. Battaglia GM, Zheng D, Hickner RC, Houmard JA. Effect of exercise training on metabolic flexibility in response to a high-fat diet in obese individuals. Am J Physiol Endocrinol Metab. (2012) 303:E1440-5. doi: 10.1152/ajpendo.00355.2012

63. Wasilewska N, Lebensztejn DM. Non-alcoholic fatty liver disease and lipotoxicity. Clin Exp Hepatol. (2021) 7:1-6. doi: 10.5114/ceh.2021.104441

64. Geng Y, Faber KN, de Meijer VE, Blokzijl H, Moshage H. How does hepatic lipid accumulation lead to lipotoxicity in non-alcoholic fatty liver disease? Hepatol Int. (2021) 15:21-35. doi: 10.1007/s12072-020-10 121-2

65. Parola M, Pinzani M. Liver fibrosis: Pathophysiology, pathogenetic targets and clinical issues. Mol Aspects Med. (2019) 65:37-55. doi: 10.1016/j.mam.2018.09.002

66. Friedman SL, Neuschwander-Tetri BA, Rinella M, Sanyal AJ. Mechanisms of NAFLD development and therapeutic strategies. Nat Med. (2018) 24:908922. doi: 10.1038/s41591-018-0104-9

67. Parthasarathy G, Revelo X, Malhi H. Pathogenesis of nonalcoholic steatohepatitis: an overview. Hepatol Commun. (2020) 4:478-92. doi: 10.1002/hep4.1479

68. Alkhouri N, Dixon LJ, Feldstein AE. Lipotoxicity in nonalcoholic fatty liver disease: not all lipids are created equal. Expert Rev Gastroenterol Hepatol. (2009) 3:445-51. doi: 10.1586/egh.09.32

69. Rada P, González-Rodríguez Á, García-Monzón C, Valverde ÁM. Understanding lipotoxicity in NAFLD pathogenesis: is CD36 a key driver? Cell Death Dis. (2020) 11:802. doi: 10.1038/s41419-020-03003-w

70. Besse-Patin A, Léveillé M, Oropeza D, Nguyen BN, Prat A, Estall JL. Estrogen signals through peroxisome proliferator-activated receptor\&\#x2212;\&\#x3b3; coactivator $1 \& \# \mathrm{x} 3 \mathrm{~b} 1$; to reduce oxidative damage associated with diet-induced fatty liver disease. Gastroenterology. (2017) 152:243-56. doi: 10.1053/j.gastro.2016.09.017

71. Chen Z, Tian R, She Z, Cai J, Li H. Role of oxidative stress in the pathogenesis of nonalcoholic fatty liver disease. Free Rad Biol Med. (2020) 152:116-41. doi: 10.1016/j.freeradbiomed.2020.02.025

72. Kim S, Park S, Kim B, Kwon J. Toll-like receptor 7 affects the pathogenesis of non-alcoholic fatty liver disease. Sci Rep. (2016) 6:27849. doi: 10.1038/srep27849

73. Rector RS, Thyfault JP, Uptergrove GM, Morris EM, Naples SP, Borengasser SJ, et al. Mitochondrial dysfunction precedes insulin resistance and hepatic steatosis and contributes to the natural history of non-alcoholic fatty liver disease in an obese rodent model. J Hepatol. (2010) 52:727-36. doi: 10.1016/j.jhep.2009.11.030

74. Delli Bovi AP, Marciano F, Mandato C, Siano MA, Savoia M, Vajro P. Oxidative stress in non-alcoholic fatty liver disease. An updated mini review. Front Med. (2021) 8:165. doi: 10.3389/fmed.2021.595371

75. Dallio M, Sangineto M, Romeo M, Villani R, Romano AD, Loguercio C, et al. Immunity as cornerstone of non-alcoholic fatty liver disease: the contribution of oxidative stress in the disease progression. Int J Mol Sci. (2021) 22:10436. doi: 10.3390/ijms22010436

76. Patterson RE, Kalavalapalli S, Williams CM, Nautiyal M, Mathew JT, Martinez J, et al. Lipotoxicity in steatohepatitis occurs despite an increase in tricarboxylic acid cycle activity. Am J Physiol Endocrinol Metab. (2016) 310:E484-94. doi: 10.1152/ajpendo.00492.2015

77. Masarone M, Rosato V, Dallio M, Gravina AG, Aglitti A, Loguercio C, et al. Role of oxidative stress in pathophysiology of nonalcoholic fatty liver disease. Oxid Med Cell Longev. (2018) 2018:9547613. doi: 10.1155/2018/9547613

78. Ibrahim SH, Akazawa Y, Cazanave SC, Bronk SF, Elmi NA, Werneburg NW, et al. Correction: Mixed lineage kinase 3 mediates release of C-X-C motif ligand 10-bearing chemotactic extracellular vesicles from lipotoxic hepatocytes. Hepatology. (2016) 64:702-2. doi: 10.1002/hep.2 8662

79. Carotti S, Aquilano K, Zalfa F, Ruggiero S, Valentini F, Zingariello M, et al. Lipophagy impairment is associated with disease progression in NAFLD. Front Physiol. (2020) 11:850. doi: 10.3389/fphys.2020.00850

80. Kao CY, Papoutsakis ET. Extracellular vesicles: exosomes, microparticles, their parts, and their targets to enable their biomanufacturing and clinical applications. Curr Opin Biotechnol. (2019) 60:89-98. doi: 10.1016/j.copbio.2019.01.005

81. Povero D, Panera N, Eguchi A, Johnson CD, Papouchado BG, de Araujo Horcel L, et al. Lipid-induced hepatocyte-derived extracellular vesicles regulate hepatic stellate cell via microRNAs targeting PPAR- $\gamma$. Cell Mol Gastroenterol Hepatol. (2015) 1:646-663.e4. doi: 10.1016/j.jcmgh.2015. 07.007

82. Hirsova P, Ibrahim SH, Krishnan A, Verma VK, Bronk SF, Werneburg NW, et al. Lipid-Induced Signaling Causes Release of Inflammatory Extracellular Vesicles From Hepatocytes. Gastroenterology. (2016) 150:95667. doi: 10.1053/j.gastro.2015.12.037 
83. Wang H, Mehal W, Nagy LE, Rotman Y. Immunological mechanisms and therapeutic targets of fatty liver diseases. Cell Mol Immunol. (2021) 18:73-91. doi: 10.1038/s41423-020-00579-3

84. Lee UE, Friedman SL. Mechanisms of hepatic fibrogenesis. Best Pract Res Clin Gastroenterol. (2011) 25:195-206. doi: 10.1016/j.bpg.2011.02.005

85. Newman LA, Sorich MJ, Rowland A. Role of extracellular vesicles in the pathophysiology, diagnosis and tracking of non-alcoholic fatty liver disease. J Clin Med. (2020) 9:72032. doi: 10.3390/jcm9072032

86. Luci C, Bourinet $M$, Leclère PS, Anty R, Gual P. Chronic inflammation in non-alcoholic steatohepatitis: molecular mechanisms and therapeutic strategies. Front Endocrinol. (2020) 11:e597648. doi: 10.3389/fendo.2020.597648

87. Pellicoro A, Ramachandran P, Iredale JP, Fallowfield JA. Liver fibrosis and repair: immune regulation of wound healing in a solid organ. Nat Rev Immunol. (2014) 14:181-94. doi: 10.1038/nri3623

88. Higashi T, Friedman SL, Hoshida Y. Hepatic stellate cells as key target in liver fibrosis. Adv Drug Deliv Rev. (2017) 121:27-42. doi: 10.1016/j.addr.2017.05.007

89. Schwabe RF, Tabas I, Pajvani UB. Mechanisms of fibrosis development in nonalcoholic steatohepatitis. Gastroenterology. (2020) 158:1913-28. doi: 10.1053/j.gastro.2019.11.311

90. Naba A, Clauser KR, Whittaker CA, Carr SA, Tanabe KK, Hynes RO. Extracellular matrix signatures of human primary metastatic colon cancers and their metastases to liver. BMC Cancer. (2014) 14:518. doi: 10.1186/1471-2407-14-518

91. McQuitty CE, Williams R, Chokshi S, Urbani L. Immunomodulatory role of the extracellular matrix within the liver disease microenvironment. Front Immunol. (2020) 11:e574276. doi: 10.3389/fimmu.2020.574276

92. Roeb E. Matrix metalloproteinases and liver fibrosis (translational aspects). Matrix Biol. (2018) 68-9:463-73. doi: 10.1016/j.matbio.2017.12.012

93. Yoshiji H, Kuriyama S, Yoshii J, Ikenaka Y, Noguchi R, Nakatani T, et al. Tissue inhibitor of metalloproteinases- 1 attenuates spontaneous liver fibrosis resolution in the transgenic mouse. Hepatology. (2002) 36:850-60. doi: 10.1053/jhep.2002.35625

94. Arteel GE, Naba A. The liver matrisome - looking beyond collagens. JHEP Rep. (2020) 2:100115. doi: 10.1016/j.jhepr.2020.100115

95. Geerts A. History, heterogeneity, developmental biology, and functions of quiescent hepatic stellate cells. Semin Liver Dis. (2001) 21:311-35. doi: 10.1055/s-2001-17550

96. Zhang F, Wang F, He J, Lian N, Wang Z, Shao J, et al. Regulation of hepatic stellate cell contraction and cirrhotic portal hypertension by $\mathrm{Wnt} / \beta$-catenin signalling via interaction with Gli1. Br J Pharmacol. (2021) 178:2246-65. doi: 10.1111/bph.15289

97. Zeisberg $M$, Yang C, Martino M, Duncan MB, Rieder F, Tanjore $\mathrm{H}$, et al. Fibroblasts derive from hepatocytes in liver fibrosis via epithelial to mesenchymal transition. J Biol Chem. (2007) 282:23337-47. doi: 10.1074/jbc.M700194200

98. Breitkopf K, Godoy P, Ciuclan L, Singer MV, Dooley S. TGF-beta/Smad signaling in the injured liver. $Z$ Gastroenterol. (2006) 44:57-66. doi: 10.1055/s-2005-858989

99. Hellerbrand C, Stefanovic B, Giordano F, Burchardt ER, Brenner DA. The role of TGF\&\#x3b2;1 in initiating hepatic stellate cell activation in vivo. $J$ Hepatol. (1999) 30:77-87. doi: 10.1016/S0168-8278(99)80010-5

100. Tsuchida T, Friedman SL. Mechanisms of hepatic stellate cell activation. Nat Rev Gastroenterol Hepatol. (2017) 14:397-411. doi: 10.1038/nrgastro.2017.38

101. Fadok VA, Bratton DL, Konowal A, Freed PW, Westcott JY, Henson PM. Macrophages that have ingested apoptotic cells in vitro inhibit proinflammatory cytokine production through autocrine/paracrine mechanisms involving TGF-beta, PGE2, and PAF. J Clin Invest. (1998) 101:890-8. doi: 10.1172/JCI1112

102. Canbay A, Taimr P, Torok N, Higuchi H, Friedman S, Gores GJ. Apoptotic body engulfment by a human stellate cell line is profibrogenic. Lab Investig. (2003) 83:655-63. doi: 10.1097/01.LAB.0000069036.63405.5C

103. Pinzani M. PDGF and signal transduction in hepatic stellate cells. Front Biosci. (2002) 7:d1720-6. doi: 10.2741/A875

104. Tan Z, Qian X, Jiang R, Liu Q, Wang Y, Chen C, et al. IL-17A plays a critical role in the pathogenesis of liver fibrosis through hepatic stellate cell activation. J Immunol. (2013) 191:1835-44. doi: 10.4049/jimmunol.1203013
105. Saxena NK, Anania FA. Adipocytokines and hepatic fibrosis. Trends Endocrinol Metab. (2015) 26:153-61. doi: 10.1016/j.tem.2015.01.002

106. Watanabe A, Hashmi A, Gomes DA, Town T, Badou A, Flavell RA, et al. Apoptotic hepatocyte DNA inhibits hepatic stellate cell chemotaxis via toll-like receptor 9. Hepatology. (2007) 46:1509-18. doi: 10.1002/hep.21867

107. Paik YH, Schwabe RF, Bataller R, Russo MP, Jobin C, Brenner DA. Toll-like receptor 4 mediates inflammatory signaling by bacterial lipopolysaccharide in human hepatic stellate cells. Hepatology. (2003) 37:1043-55. doi: 10.1053/jhep.2003.50182

108. Seki E, De Minicis S, Österreicher CH, Kluwe J, Osawa Y, Brenner DA, et al. TLR4 enhances TGF- $\beta$ signaling and hepatic fibrosis. Nat Med. (2007) 13:1324-32. doi: 10.1038/nm1663

109. Zhu C, Kim K, Wang X, Bartolome A, Salomao M, Dongiovanni $\mathrm{P}$, et al. Hepatocyte Notch activation induces liver fibrosis in nonalcoholic steatohepatitis. Sci Transl Med. (2018) 10:aat0344. doi: 10.1126/scitranslmed.aat0344

110. Rangwala F, Guy CD, Lu J, Suzuki A, Burchette JL, Abdelmalek MF, et al. Increased production of sonic hedgehog by ballooned hepatocytes. J Pathol. (2011) 224:401-10. doi: 10.1002/path.2888

111. Mannaerts I, Leite SB, Verhulst S, Claerhout S, Eysackers N, Thoen LF, et al. The Hippo pathway effector YAP controls mouse hepatic stellate cell activation. J Hepatol. (2015) 63:679-88. doi: 10.1016/j.jhep.2015.04.011

112. Urtasun R, Lopategi A, George J, Leung TM, Lu Y, Wang X, et al. Osteopontin, an oxidant stress sensitive cytokine, up-regulates collagen-I via integrin $\alpha(\mathrm{V}) \beta(3)$ engagement and PI3K/pAkt/NFאB signaling. Hepatology. (2012) 55:594-608. doi: 10.1002/hep.24701

113. Tomita K, Teratani T, Suzuki T, Shimizu M, Sato H, Narimatsu K, et al. Free cholesterol accumulation in hepatic stellate cells: mechanism of liver fibrosis aggravation in nonalcoholic steatohepatitis in mice. Hepatology. (2014) 59:154-69. doi: 10.1002/hep.26604

114. Meyaard L. LAIR and collagens in immune regulation. Immunol Lett. (2010) 128:26-8. doi: 10.1016/j.imlet.2009.09.014

115. Olaso E, Ikeda K, Eng FJ, Xu L, Wang LH, Lin HC, et al. DDR2 receptor promotes MMP-2-mediated proliferation and invasion by hepatic stellate cells. J Clin Invest. (2001) 108:1369-78. doi: 10.1172/JCI200112373

116. Frevert CW, Felgenhauer J, Wygrecka M, Nastase MV, Schaefer L. Dangerassociated molecular patterns derived from the extracellular matrix provide temporal control of innate immunity. J Histochem Cytochem. (2018) 66:21327. doi: $10.1369 / 0022155417740880$

117. Ramnath D, Irvine KM, Lukowski SW, Horsfall LU, Loh Z, Clouston $\mathrm{AD}$, et al. Hepatic expression profiling identifies steatosis-independent and steatosis-driven advanced fibrosis genes. JCI Insight. (2018) 3:120274. doi: 10.1172/jci.insight. 120274

118. Zhu M, Wang Q, Zhou W, Liu T, Yang L, Zheng P, et al. Integrated analysis of hepatic mRNA and miRNA profiles identified molecular networks and potential biomarkers of NAFLD. Scientific Reports. (2018) 8:7628. doi: 10.1038/s41598-018-25743-8

119. Li Y, Turpin CP, Wang S. Role of thrombospondin 1 in liver diseases. Hepatol Res. (2017) 47:186-193. doi: 10.1111/hepr.12787

120. Bian Z, Peng Y, You Z, Wang Q, Miao Q, Liu Y, et al. CCN1 expression in hepatocytes contributes to macrophage infiltration in nonalcoholic fatty liver disease in mice. J Lipid Res. (2013) 54:44-54. doi: 10.1194/jlr.M026013

121. Charlton M, Viker K, Krishnan A, Sanderson S, Veldt B, Kaalsbeek AJ, et al. Differential expression of lumican and fatty acid binding protein-1: new insights into the histologic spectrum of nonalcoholic fatty liver disease. Hepatology. (2009) 49:1375-84. doi: 10.1002/hep.22927

122. Lu Y, Liu X, Jiao Y, Xiong X, Wang E, Wang X, et al. Periostin promotes liver steatosis and hypertriglyceridemia through downregulation of PPAR $\alpha$. J Clin Investig. (2014) 124:3501-13. doi: 10.1172/JCI7 4438

123. Yang Z, Zhang $\mathrm{H}$, Niu $\mathrm{Y}$, Zhang W, Zhu L, Li X, et al. Circulating periostin in relation to insulin resistance and nonalcoholic fatty liver disease among overweight and obese subjects. Sci Rep. (2016) 6:37886. doi: $10.1038 /$ srep37886

124. Fan W, Liu T, Chen W, Hammad S, Longerich T, Hausser I, et al. ECM1 prevents activation of transforming growth factor $\beta$, hepatic stellate cells, and fibrogenesis in mice. Gastroenterology. (2019) 157:1352-67.e13. doi: 10.1053/j.gastro.2019.07.036 
125. Bollyky PL, Falk BA, Wu RP, Buckner JH, Wight TN, Nepom GT. Intact extracellular matrix and the maintenance of immune tolerance: high molecular weight hyaluronan promotes persistence of induced CD4+CD25+ regulatory T cells. J Leukocyte Biol. (2009) 86:567-72. doi: 10.1189/jlb.0109001

126. Karsdal MA, Manon-Jensen T, Genovese F, Kristensen JH, Nielsen MJ, Sand $\mathrm{JM}$, et al. Novel insights into the function and dynamics of extracellular matrix in liver fibrosis. Am J Physiol Gastrointest Liver Physiol. (2015) 308:G807-30. doi: 10.1152/ajpgi.00447.2014

127. Novo E, Bocca C, Foglia B, Protopapa F, Maggiora M, Parola M, et al. Liver fibrogenesis: un update on established and emerging basic concepts. Arch Biochem Biophys. (2020) 689:108445. doi: 10.1016/j.abb.2020.108445

128. Guillot A, Hamdaoui N, Bizy A, Zoltani K, Souktani R, Zafrani ES, et al. Cannabinoid receptor 2 counteracts interleukin-17-induced immune and fibrogenic responses in mouse liver. Hepatology. (2014) 59:296-306. doi: 10.1002/hep. 26598

129. Leroux A, Ferrere G, Godie V, Cailleux F, Renoud ML, Gaudin F, et al. Toxic lipids stored by Kupffer cells correlates with their pro-inflammatory phenotype at an early stage of steatohepatitis. J Hepatol. (2012) 57:141-9. doi: 10.1016/j.jhep.2012.02.028

130. Kazankov K, Jørgensen SMD, Thomsen KL, Møller HJ, Vilstrup H, George $\mathrm{J}$, et al. The role of macrophages in nonalcoholic fatty liver disease and nonalcoholic steatohepatitis. Nat Rev Gastroenterol Hepatol. (2019) 16:14559. doi: 10.1038/s41575-018-0082-x

131. Paquissi FC. Immune imbalances in non-alcoholic fatty liver disease: from general biomarkers and neutrophils to interleukin-17 axis activation and new therapeutic targets. Front Immunol. (2016) 7:490. doi: 10.3389/fimmu.2016.00490

132. Cai J, Xu M, Zhang X, Li H. Innate immune signaling in nonalcoholic fatty liver disease and cardiovascular diseases. Annu Rev Pathol. (2019) 14:153-84. doi: 10.1146/annurev-pathmechdis-012418-013003

133. Saeed S, Quintin J, Kerstens HHD, Rao NA, Aghajanirefah A, Matarese F, et al. Epigenetic programming of monocyte-to-macrophage differentiation and trained innate immunity. Science. (2014) 345:1251086. doi: 10.1126/science.1251086

134. Netea MG, Domínguez-Andrés J, Barreiro LB, Chavakis T, Divangahi M, Fuchs E, et al. Defining trained immunity and its role in health and disease. Nat Rev Immunol. (2020) 20:375-88. doi: 10.1038/s41577-020-0285-6

135. Netea MG, Joosten LA, Latz E, Mills KH, Natoli G, Stunnenberg HG, et al. Trained immunity: A program of innate immune memory in health and disease. Science. (2016) 352:aaf1098. doi: 10.1126/science.aaf 1098

136. Gong T, Liu L, Jiang W, Zhou R. DAMP-sensing receptors in sterile inflammation and inflammatory diseases. Nat Rev Immunol. (2020) 20:95112. doi: 10.1038/s41577-019-0215-7

137. Arrese M, Cabrera D, Kalergis AM, Feldstein AE. Innate immunity and inflammation in NAFLD/NASH. Dig Dis Sci. (2016) 61:1294-303. doi: 10.1007/s10620-016-4049-x

138. Yatim N, Cullen S, Albert ML. Dying cells actively regulate adaptive immune responses. Nat Rev Immunol. (2017) 17:262-75. doi: 10.1038/nri.2017.9

139. Kazama H, Ricci JE, Herndon JM, Hoppe G, Green DR, Ferguson TA. Induction of immunological tolerance by apoptotic cells requires caspasedependent oxidation of high-mobility group box-1 protein. Immunity. (2008) 29:21-32. doi: 10.1016/j.immuni.2008.05.013

140. Miura K, Kodama Y, Inokuchi S, Schnabl B, Aoyama T, Ohnishi $\mathrm{H}$, et al. Toll-like receptor 9 promotes steatohepatitis by induction of interleukin-1beta in mice. Gastroenterology. (2010) 139:323-34.e7. doi: 10.1053/j.gastro.2010.03.052

141. Etienne-Mesmin L, Vijay-Kumar M, Gewirtz AT, Chassaing B. Hepatocyte toll-like receptor 5 promotes bacterial clearance and protects mice against high-fat diet\&\#x2013; induced liver disease. Cell Mol Gastroenterol Hepatol. (2016) 2:584-604. doi: 10.1016/j.jcmgh.2016.04.007

142. Miura K, Ohnishi H. Role of gut microbiota and toll-like receptors in nonalcoholic fatty liver disease. World J Gastroenterol. (2014) 20:7381-91. doi: 10.3748/wjg.v20.i23.7381

143. Lee JY, Sohn KH, Rhee SH, Hwang D. Saturated fatty acids, but not unsaturated fatty acids, induce the expression of cyclooxygenase-2 mediated through toll-like receptor 4 *. J Biol Chem. (2001) 276:16683-9. doi: 10.1074/jbc.M011695200
144. Böhm T, Berger H, Nejabat M, Riegler T, Kellner F, Kuttke M, et al. Food-derived peroxidized fatty acids may trigger hepatic inflammation: A novel hypothesis to explain steatohepatitis. J Hepatol. (2013) 59:563-70. doi: 10.1016/j.jhep.2013.04.025

145. Ioannou GN, Subramanian S, Chait A, Haigh WG, Yeh MM, Farrell GC, et al. Cholesterol crystallization within hepatocyte lipid droplets and its role in murine NASH. J Lipid Res. (2017) 58:1067-79. doi: 10.1194/jlr.M072454

146. Adolph TE, Grander C, Grabherr F, Tilg H. Adipokines and non-alcoholic fatty liver disease: multiple interactions. Int J Mol Sci. (2017) 18:1649. doi: 10.3390/ijms18081649

147. Méndez-Sánchez N, Valencia-Rodríguez A, Coronel-Castillo C, Vera-Barajas A, Contreras-Carmona J, Ponciano-Rodríguez G, et al. The cellular pathways of liver fibrosis in non-alcoholic steatohepatitis. Ann Transl Med. (2020) 8:400. doi: 10.21037/atm.2020.02.184

148. Peiseler M, Tacke F. Inflammatory mechanisms underlying nonalcoholic steatohepatitis and the transition to hepatocellular carcinoma. Cancers. (2021) 13:730. doi: 10.3390/cancers 13040730

149. Hotamisligil GS. Inflammation, metaflammation and immunometabolic disorders. Nature. (2017) 542:177-85. doi: 10.1038/nature21363

150. Diedrich T, Kummer S, Galante A, Drolz A, Schlicker V, Lohse AW, et al. Characterization of the immune cell landscape of patients with NAFLD. PLoS ONE. (2020) 15:e0230307. doi: 10.1371/journal.pone.0230307

151. Guilliams M, Dutertre CA, Scott CL, McGovern N, Sichien D, Chakarov S, et al. Unsupervised high-dimensional analysis aligns dendritic cells across tissues and species. Immunity. (2016) 45:669-84. doi: 10.1016/j.immuni.2016.08.015

152. Wake K, Decker K, Kirn A, Knook DL, McCuskey RS, Bouwens L, et al. Cell biology and kinetics of Kupffer cells in the liver. Int Rev Cytol. (1989) 118:173-229. doi: 10.1016/S0074-7696(08)60875-X

153. Tacke F, Zimmermann HW. Macrophage heterogeneity in liver injury and fibrosis. J Hepatol. (2014) 60:1090-6. doi: 10.1016/j.jhep.2013.12.025

154. David BA, Rezende RM, Antunes MM, Santos MM, Freitas Lopes MA, Diniz $\mathrm{AB}$, et al. Combination of mass cytometry and imaging analysis reveals origin, location, and functional repopulation of liver myeloid cells in mice. Gastroenterology. (2016) 151:1176-91. doi: 10.1053/j.gastro.2016.08.024

155. MacPhee PJ, Schmidt EE, Groom AC. Evidence for Kupffer cell migration along liver sinusoids, from high-resolution in vivo microscopy. Am J Physiol. (1992) 263:G17-23. doi: 10.1152/ajpgi.1992.263.1.G17

156. Tacke F. Targeting hepatic macrophages to treat liver diseases. J Hepatol. (2017) 66:1300-12. doi: 10.1016/j.jhep.2017.02.026

157. Krenkel O, Tacke F. Liver macrophages in tissue homeostasis and disease. Nat Rev Immunol. (2017) 17:306-21. doi: 10.1038/nri.2017.11

158. MacParland SA, Liu JC, Ma XZ, Innes BT, Bartczak AM, Gage BK, et al. Single cell RNA sequencing of human liver reveals distinct intrahepatic macrophage populations. Nat Commun. (2018) 9:4383. doi: 10.1038/s41467-018-06318-7

159. Krenkel O, Hundertmark J, Abdallah AT, Kohlhepp M, Puengel T, Roth T, et al. Myeloid cells in liver and bone marrow acquire a functionally distinct inflammatory phenotype during obesity-related steatohepatitis. Gut. (2020) 69:551-63. doi: 10.1136/gutjnl-2019-318382

160. Heymann F, Tacke F. Immunology in the liver-from homeostasis to disease. Nat Rev Gastroenterol Hepatol. (2016) 13:88-110. doi: 10.1038/nrgastro.2015.200

161. Wan J, Benkdane M, Teixeira-Clerc F, Bonnafous S, Louvet A, Lafdil F, et al. M2 Kupffer cells promote M1 Kupffer cell apoptosis: a protective mechanism against alcoholic and nonalcoholic fatty liver disease. Hepatology. (2014) 59:130-42. doi: 10.1002/hep.26607

162. Baeck C, Wehr A, Karlmark KR, Heymann F, Vucur M, Gassler N, et al. Pharmacological inhibition of the chemokine CCL2 (MCP-1) diminishes liver macrophage infiltration and steatohepatitis in chronic hepatic injury. Gut. (2012) 61:416-26. doi: 10.1136/gutjnl-2011-300304

163. Wu Z, Han M, Chen $T$, Yan W, Ning Q. Acute liver failure: mechanisms of immune-mediated liver injury. Liver Int. (2010) 30:782-94. doi: 10.1111/j.1478-3231.2010.0 2262.x

164. Wynn TA, Barron L. Macrophages: master regulators of inflammation and fibrosis. Semin Liver Dis. (2010) 30:245-57. doi: 10.1055/s-0030-1255354

165. Schuppan D, Surabattula R, Wang XY. Determinants of fibrosis progression and regression in NASH. J Hepatol. (2018) 68:238-50. doi: 10.1016/j.jhep.2017.11.012 
166. Boltjes A, Movita D, Boonstra A, Woltman AM. The role of Kupffer cells in hepatitis B and hepatitis C virus infections. J Hepatol. (2014) 61:660-71. doi: 10.1016/j.jhep.2014.04.026

167. Miura K, Ishioka M, Minami S, Horie Y, Ohshima S, Goto T, et al. Toll-like receptor 4 on macrophage promotes the development of steatohepatitisrelated hepatocellular carcinoma in mice. J Biol Chem. (2016) 291:11504-17. doi: 10.1074/jbc.M115.709048

168. Qian BZ, Pollard JW. Macrophage diversity enhances tumor progression and metastasis. Cell. (2010) 141:39-51. doi: 10.1016/j.cell.2010.03.014

169. Gadd VL, Skoien R, Powell EE, Fagan KJ, Winterford C, Horsfall L, et al. The portal inflammatory infiltrate and ductular reaction in human nonalcoholic fatty liver disease. Hepatology. (2014) 59:1393-405. doi: 10.1002/hep.26937

170. Lotowska JM, Sobaniec-Lotowska ME, Lebensztejn DM. The role of Kupffer cells in the morphogenesis of nonalcoholic steatohepatitis - ultrastructural findings. The first report in pediatric patients. Scand J Gastroenterol. (2013) 48:352-7. doi: 10.3109/00365521.2012.746390

171. Henning JR, Graffeo CS, Rehman A, Fallon NC, Zambirinis CP, Ochi A, et al. Dendritic cells limit fibroinflammatory injury in nonalcoholic steatohepatitis in mice. Hepatology. (2013) 58:589-602. doi: 10.1002/hep.26267

172. Mantovani A, Schioppa T, Porta C, Allavena P, Sica A. Role of tumorassociated macrophages in tumor progression and invasion. Cancer Metastasis Rev. (2006) 25:315-22. doi: 10.1007/s10555-006-9001-7

173. Seo YY, Cho YK, Bae JC, Seo MH, Park SE, Rhee EJ, et al. Tumor necrosis factor- $\alpha$ as a predictor for the development of nonalcoholic fatty liver disease: a 4-year follow-up study. Endocrinol Metab. (2013) 28:41-5. doi: 10.3803/EnM.2013.28.1.41

174. Kamari Y, Shaish A, Vax E, Shemesh S, Kandel-Kfir M, Arbel Y, et al. Lack of interleukin- $1 \alpha$ or interleukin- $1 \beta$ inhibits transformation of steatosis to steatohepatitis and liver fibrosis in hypercholesterolemic mice. J Hepatol. (2011) 55:1086-94. doi: 10.1016/j.jhep.2011.01.048

175. Tilg H, Effenberger M, Adolph TE. A role for IL-1 inhibitors in the treatment of non-alcoholic fatty liver disease (NAFLD)? Expert Opin Investig Drugs. (2020) 29:103-6. doi: 10.1080/13543784.2020.1681397

176. Hung J, McQuillan BM, Chapman CM, Thompson PL, Beilby JP. Elevated interleukin-18 levels are associated with the metabolic syndrome independent of obesity and insulin resistance. Arterioscler Thromb Vasc Biol. (2005) 25:1268-73. doi: 10.1161/01.ATV.0000163843.70369.12

177. Henao-Mejia J, Elinav E, Jin C, Hao L, Mehal WZ, Strowig T, et al. Inflammasome-mediated dysbiosis regulates progression of NAFLD and obesity. Nature. (2012) 482:179-85. doi: 10.1038/nature10809

178. Wei Y, Tian Q, Zhao X, Wang X. Serum transforming growth factor beta 3 predicts future development of nonalcoholic fatty liver disease. Int J Clin Exp Med. (2015) 8:4545-50.

179. Kazankov K, Barrera F, Møller HJ, Rosso C, Bugianesi E, David E, et al. The macrophage activation marker sCD163 is associated with morphological disease stages in patients with non-alcoholic fatty liver disease. Liver Int. (2016) 36:1549-57. doi: 10.1111/liv.13150

180. Kazankov K, Alisi A, Møller HJ, De Vito R, Rittig S, Mahler $B$, et al. Macrophage markers are poorly associated with liver histology in children with nonalcoholic fatty liver disease. J Pediatr Gastroenterol Nutr. (2018) 67:635-42. doi: 10.1097/MPG.00000000000 02111

181. Jiang ZG, Sandhu B, Feldbrügge L, Yee EU, Csizmadia E, Mitsuhashi S, et al. Serum activity of macrophage-derived adenosine deaminase 2 is associated with liver fibrosis in nonalcoholic fatty liver disease. Clin Gastroenterol Hepatol. (2018) 16:1170-2. doi: 10.1016/j.cgh.2017.11.028

182. Thomson AW, Drakes ML, Zahorchak AF, O'Connell PJ, Steptoe RJ, Qian S, et al. Hepatic dendritic cells: immunobiology and role in liver transplantation. J Leukoc Biol. (1999) 66:322-30. doi: 10.1002/jlb.66.2.322

183. Almeda-Valdes P, Aguilar Olivos NE, Barranco-Fragoso B, Uribe M, Méndez-Sánchez N. The role of dendritic cells in fibrosis progression in nonalcoholic fatty liver disease. Biomed Res Int. (2015) 2015:768071. doi: $10.1155 / 2015 / 768071$

184. Lukacs-Kornek V, Schuppan D. Dendritic cells in liver injury and fibrosis: shortcomings and promises. J Hepatol. (2013) 59:1124-6. doi: 10.1016/j.jhep.2013.05.033

185. Ibrahim J, Nguyen AH, Rehman A, Ochi A, Jamal M, Graffeo CS, et al. Dendritic cell populations with different concentrations of lipid regulate tolerance and immunity in mouse and human liver. Gastroenterology. (2012) 143:1061-72. doi: 10.1053/j.gastro.2012.06.003

186. Liu K, Wang FS, Xu R. Neutrophils in liver diseases: pathogenesis and therapeutic targets. Cell Mol Immunol. (2021) 18:38-44. doi: 10.1038/s41423-020-00560-0

187. Cai J, Zhang XJ, Li H. The role of innate immune cells in nonalcoholic steatohepatitis. Hepatology. (2019) 70:1026-37. doi: 10.1002/hep.30506

188. Ramaiah SK, Jaeschke H. Role of neutrophils in the pathogenesis of acute inflammatory liver injury. Toxicol Pathol. (2007) 35:757-66. doi: 10.1080/01926230701584163

189. Nati M, Haddad D, Birkenfeld AL, Koch CA, Chavakis T, Chatzigeorgiou A. The role of immune cells in metabolism-related liver inflammation and development of non-alcoholic steatohepatitis (NASH). Rev Endocr Metab Disord. (2016) 17:29-39. doi: 10.1007/s11154-016-9339-2

190. Tanwar S, Rhodes F, Srivastava A, Trembling PM, Rosenberg WM. Inflammation and fibrosis in chronic liver diseases including non-alcoholic fatty liver disease and hepatitis C. World J Gastroenterol. (2020) 26:109-33. doi: 10.3748/wjg.v26.i2.109

191. Tang J, Yan Z, Feng Q, Yu L, Wang H. The roles of neutrophils in the pathogenesis of liver diseases. Front Immunol. (2021) 12:625472. doi: 10.3389/fimmu.2021.625472

192. Khoury T, Mari A, Nseir W, Kadah A, Sbeit W, Mahamid M. Neutrophil-tolymphocyte ratio is independently associated with inflammatory activity and fibrosis grade in nonalcoholic fatty liver disease. Eur J Gastroenterol Hepatol. (2019) 31:1110-5. doi: 10.1097/MEG.0000000000001393

193. Miyagi T, Takehara T, Uemura A, Nishio K, Shimizu S, Kodama T, et al. Absence of invariant natural killer $\mathrm{T}$ cells deteriorates liver inflammation and fibrosis in mice fed high-fat diet. J Gastroenterol. (2010) 45:1247-54. doi: 10.1007/s00535-010-0272-y

194. van der Windt DJ, Sud V, Zhang H, Varley PR, Goswami J, Yazdani HO, et al. Neutrophil extracellular traps promote inflammation and development of hepatocellular carcinoma in nonalcoholic steatohepatitis. Hepatology. (2018) 68:1347-60. doi: 10.1002/hep.29914

195. Mirea AM, Toonen EJM, van den Munckhof I, Munsterman ID, Tjwa TTL, Jaeger M, et al. Increased proteinase 3 and neutrophil elastase plasma concentrations are associated with non-alcoholic fatty liver disease (NAFLD) and type 2 diabetes. Mol Med. (2019) 25:16. doi: 10.1186/s10020-019-0084-3

196. Talukdar S, Oh DY, Bandyopadhyay G, Li D, Xu J, McNelis J, et al. Neutrophils mediate insulin resistance in mice fed a high-fat diet through secreted elastase. Nat Med. (2012) 18:1407-12. doi: 10.1038/nm.2885

197. Martinez-Chantar ML, Delgado TC, Beraza N. Revisiting the role of natural killer cells in non-alcoholic fatty liver disease. Front Immunol. (2021) 12:640869. doi: 10.3389/fimmu.2021.640869

198. Vivier E, Raulet DH, Moretta A, Caligiuri MA, Zitvogel L, Lanier LL, et al. Innate or adaptive immunity? The example of natural killer cells. Science. (2011) 331:44-9. doi: 10.1126/science.1198687

199. Zingoni A, Molfetta R, Fionda C, Soriani A, Paolini R, Cippitelli M, et al. NKG2D and its ligands: "one for all, all for one." Front Immunol. (2018) 9:476. doi: 10.3389/fimmu.2018.00476

200. Li T, Yang Y, Song H, Li H, Cui A, Liu Y, et al. Activated NK cells kill hepatic stellate cells via p38/PI3K signaling in a TRAILinvolved degranulation manner. J Leukocyte Biol. (2019) 105:695-704. doi: 10.1002/JLB.2A0118-031RR

201. Gur C, Doron S, Kfir-Erenfeld S, Horwitz E, Abu-tair L, Safadi R, et al. NKp46-mediated killing of human and mouse hepatic stellate cells attenuates liver fibrosis. Gut. (2012) 61:885-93. doi: 10.1136/gutjnl-2011-301400

202. Radaeva S, Sun R, Jaruga B, Nguyen VT, Tian Z, Gao B. Natural killer cells ameliorate liver fibrosis by killing activated stellate cells in NKG2D-dependent and tumor necrosis factor-related apoptosisinducing ligand-dependent manners. Gastroenterology. (2006) 130:435-52. doi: 10.1053/j.gastro.2005.10.055

203. Kahraman A, Schlattjan M, Kocabayoglu P, Yildiz-Meziletoglu S, Schlensak $\mathrm{M}$, Fingas CD, et al. Major histocompatibility complex class I-related chains A and B (MIC A/B): a novel role in nonalcoholic steatohepatitis. Hepatology. (2010) 51:92-102. doi: 10.1002/hep.23253

204. Amer J, Salhab A, Noureddin M, Doron S, Abu-Tair L, Ghantous R, et al. Insulin signaling as a potential natural killer cell checkpoint in fatty liver disease. Hepatol Commun. (2018) 2:285-98. doi: 10.1002/hep4.1146 
205. Godfrey DI, Koay H-F, McCluskey J, Gherardin NA. The biology and functional importance of MAIT cells. Nat Immunol. (2019) 20:1110-28. doi: 10.1038/s41590-019-0444-8

206. Hegde P, Weiss E, Paradis V, Wan J, Mabire M, Sukriti S, et al. Mucosalassociated invariant $\mathrm{T}$ cells are a profibrogenic immune cell population in the liver. Nat Commun. (2018) 9:2146. doi: 10.1038/s41467-018-04450-y

207. Li Y, Huang B, Jiang X, Chen W, Zhang J, Wei Y, et al. Mucosalassociated invariant $\mathrm{T}$ cells improve nonalcoholic fatty liver disease through regulating macrophage polarization. Front Immunol. (2018) 9:1994. doi: 10.3389/fimmu.2018.01994

208. Kremer M, Hines IN. Natural killer T cells and non-alcoholic fatty liver disease: fat chews on the immune system. World J Gastroenterol. (2008) 14:487-8. doi: 10.3748/wjg. 14.487

209. Syn WK, Agboola KM, Swiderska M, Michelotti GA, Liaskou E, Pang $\mathrm{H}$, et al. NKT-associated hedgehog and osteopontin drive fibrogenesis in non-alcoholic fatty liver disease. Gut. (2012) 61:1323-9. doi: 10.1136/gutjnl-2011-301857

210. Maricic I, Marrero I, Eguchi A, Nakamura R, Johnson CD, Dasgupta S, et al. Differential activation of hepatic invariant NKT cell subsets plays a key role in progression of nonalcoholic steatohepatitis. J Immunol. (2018) 201:3017-35. doi: 10.4049/jimmunol.1800614

211. Elinav E, Pappo O, Sklair-Levy M, Margalit M, Shibolet O, Gomori M, et al. Amelioration of non-alcoholic steatohepatitis and glucose intolerance in ob/ob mice by oral immune regulation towards liver-extracted proteins is associated with elevated intrahepatic NKT lymphocytes and serum IL-10 levels. J Pathol. (2006) 208:74-81. doi: 10.1002/path.1869

212. Martin-Murphy BV, You Q, Wang H, De La Houssaye BA, Reilly TP, Friedman JE, et al. Mice lacking natural killer T cells are more susceptible to metabolic alterations following high fat diet feeding. PLoS ONE. (2014) 9:e80949. doi: 10.1371/journal.pone.0080949

213. Welsh RM, Lin MY, Lohman BL, Varga SM, Zarozinski CC, Selin LK. Alpha beta and gamma delta T-cell networks and their roles in natural resistance to viral infections. Immunol Rev. (1997) 159:79-93. doi: 10.1111/j.1600-065X.1997.tb01008.x

214. Hammerich L, Tacke F. Role of gamma-delta $\mathrm{T}$ cells in liver inflammation and fibrosis. World J Gastrointest Pathophysiol. (2014) 5:107-13. doi: 10.4291/wjgp.v5.i2.107

215. Chen Y, Tian Z. Roles of hepatic innate and innate-like lymphocytes in nonalcoholic steatohepatitis. Front Immunol. (2020) 11:1500. doi: 10.3389/fimmu.2020.01500

216. Li F, Hao X, Chen Y, Bai L, Gao X, Lian Z, et al. The microbiota maintain homeostasis of liver-resident $\gamma \delta \mathrm{T}-17$ cells in a lipid antigen/CD1d-dependent manner. Nat Commun. (2017) 8:13839. doi: 10.1038/ncomms13839

217. Torres-Hernandez A, Wang W, Nikiforov Y, Tejada K, Torres L, Kalabin A, et al. $\gamma \delta \mathrm{T}$ Cells promote steatohepatitis by orchestrating innate and adaptive immune programming. Hepatology. (2020) 71:477-94. doi: 10.1002/hep.30952

218. Sutti S, Albano E. Adaptive immunity: an emerging player in the progression of NAFLD. Nat Rev Gastroenterol Hepatol. (2020) 17:81-92. doi: 10.1038/s41575-019-0210-2

219. Bruzzì S, Sutti S, Giudici G, Burlone ME, Ramavath NN, Toscani A, et al. B2Lymphocyte responses to oxidative stress-derived antigens contribute to the evolution of nonalcoholic fatty liver disease (NAFLD). Free Rad Biol Med. (2018) 124:249-59. doi: 10.1016/j.freeradbiomed.2018.06.015

220. Van Herck MA, Weyler J, Kwanten WJ, Dirinck EL, De Winter BY, Francque $\mathrm{SM}$, et al. The differential roles of $\mathrm{t}$ cells in non-alcoholic fatty liver disease and obesity. Front Immunol. (2019) 10:82. doi: 10.3389/fimmu.2019.00082

221. Rolla S, Alchera E, Imarisio C, Bardina V, Valente G, Cappello P, et al. The balance between IL-17 and IL-22 produced by liver-infiltrating T-helper cells critically controls NASH development in mice. Clin Sci (Lond). (2016) 130:193-203. doi: 10.1042/CS20150405

222. Sutti S, Jindal A, Locatelli I, Vacchiano M, Gigliotti L, Bozzola $\mathrm{C}$, et al. Adaptive immune responses triggered by oxidative stress contribute to hepatic inflammation in NASH. Hepatology. (2014) 59:886-97. doi: $10.1002 /$ hep. 26749

223. Luo XY, Takahara T, Kawai K, Fujino M, Sugiyama T, Tsuneyama K, et al. IFN- $\gamma$ deficiency attenuates hepatic inflammation and fibrosis in a steatohepatitis model induced by a methionine- and choline-deficient highfat diet. Am J Physiol Gastrointestinal Liver Physiol. (2013) 305:G891-9. doi: 10.1152 /ajpgi.00193.2013
224. Bertola A, Bonnafous S, Anty R, Patouraux S, Saint-Paul MC, Iannelli A, et al Hepatic expression patterns of inflammatory and immune response genes associated with obesity and NASH in morbidly obese patients. PLOS ONE. (2010) 5:e13577. doi: 10.1371/journal.pone.0013577

225. Inzaugarat ME, Ferreyra Solari NE, Billordo LA, Abecasis R, Gadano AC, Cherñavsky AC. Altered phenotype and functionality of circulating immune cells characterize adult patients with nonalcoholic steatohepatitis. J Clin Immunol. (2011) 31:1120-30. doi: 10.1007/s10875-011-9571-1

226. Rau M, Schilling AK, Meertens J, Hering I, Weiss J, Jurowich C, et al. Progression from nonalcoholic fatty liver to nonalcoholic steatohepatitis is marked by a higher frequency of Th17 cells in the liver and an increased Th17/resting regulatory $t$ cell ratio in peripheral blood and in the liver. $J$ Immunol. (2016) 196:97-105. doi: 10.4049/jimmunol.1501175

227. Harley ITW, Stankiewicz TE, Giles DA, Softic S, Flick LM, Cappelletti M, et al. IL-17 signaling accelerates the progression of nonalcoholic fatty liver disease in mice. Hepatology. (2014) 59:1830-9. doi: 10.1002/hep.26746

228. Molina MF, Abdelnabi MN, Fabre T, Shoukry NH. Type 3 cytokines in liver fibrosis and liver cancer. Cytokine. (2019) 124:154497. doi: 10.1016/j.cyto.2018.07.028

229. Meng F, Wang K, Aoyama T, Grivennikov SI, Paik Y, Scholten D, et al. Interleukin-17 signaling in inflammatory, Kupffer cells, and hepatic stellate cells exacerbates liver fibrosis in mice. Gastroenterology. (2012) 143:76576.e3. doi: $10.1053 /$ j.gastro.2012.05.049

230. Bhattacharjee J, Kirby M, Softic S, Miles L, Salazar-Gonzalez RM, Shivakumar P, et al. Hepatic natural killer T-cell and CD8+ T-cell signatures in mice with nonalcoholic steatohepatitis. Hepatol Commun. (2017) 1:299310. doi: 10.1002/hep4.1041

231. Wolf MJ, Adili A, Piotrowitz K, Abdullah Z, Boege Y, Stemmer K, et al. Metabolic activation of intrahepatic CD8+ T cells and NKT cells causes nonalcoholic steatohepatitis and liver cancer via cross-talk with hepatocytes. Cancer Cell. (2014) 26:549-64. doi: 10.1016/j.ccell.2014.09.003

232. Racanelli V, Sansonno D, Piccoli C, D'Amore FP, Tucci FA, Dammacco F. Molecular characterization of B cell clonal expansions in the liver of chronically hepatitis C virus-infected patients. J Immunol. (2001) 167:21-9. doi: 10.4049/jimmunol.167.1.21

233. Thapa M, Chinnadurai R, Velazquez VM, Tedesco D, Elrod E, Han JH, et al. Liver fibrosis occurs through dysregulation of MyD88-dependent innate B-cell activity. Hepatology. (2015) 61:2067-79. doi: 10.1002/hep.27761

234. Miyake T, Abe M, Tokumoto Y, Hirooka M, Furukawa S, Kumagi $\mathrm{T}$, et al. B cell-activating factor is associated with the histological severity of nonalcoholic fatty liver disease. Hepatol Int. (2013) 7:539-47. doi: 10.1007/s12072-012-9345-8

235. McPherson S, Henderson E, Burt AD, Day CP, Anstee QM. Serum immunoglobulin levels predict fibrosis in patients with non-alcoholic fatty liver disease. J Hepatol. (2014) 60:1055-62. doi: 10.1016/j.jhep.2014. 01.010

236. Vuppalanchi R, Noureddin M, Alkhouri N, Sanyal AJ. Therapeutic pipeline in nonalcoholic steatohepatitis. Nat Rev Gastroenterol Hepatol. (2021) 18:373-92. doi: 10.1038/s41575-020-00408-y

237. Albhaisi SAM, Sanyal AJ. New drugs for NASH. Liver Int. (2021) 41:112-8. doi: 10.1111/liv.14844

238. Lassailly G, Caiazzo R, Ntandja-Wandji L-C, Gnemmi V, Baud G, Verkindt $\mathrm{H}$, et al. Bariatric surgery provides long-term resolution of nonalcoholic steatohepatitis and regression of fibrosis. Gastroenterology. (2020) 159:1290301.e5. doi: 10.1053/j.gastro.2020.06.006

239. Feng $\mathrm{D}$. The alteration of immune cells in the pathogenesis of non-alcoholic fatty liver disease and non-alcoholic steatohepatitis. Liver Res. (2020) 4:2327. doi: 10.1016/j.livres.2020.02.003

240. El Hadi H, Vettor R, Rossato M. Vitamin E as a treatment for nonalcoholic fatty liver disease: reality or myth? Antioxidants. (2018) 7:12. doi: 10.3390/antiox7010012

241. Tacke F. Cenicriviroc for the treatment of non-alcoholic steatohepatitis and liver fibrosis. Exp Opin Investig Drugs. (2018) 27:301-11. doi: 10.1080/13543784.2018.1442436

242. Friedman SL, Ratziu V, Harrison SA, Abdelmalek MF, Aithal GP, Caballeria $\mathrm{J}$, et al. A randomized, placebo-controlled trial of cenicriviroc for treatment of nonalcoholic steatohepatitis with fibrosis. Hepatology. (2018) 67:1754-67. doi: $10.1002 /$ hep. 29477

243. Ratziu V, Sanyal A, Harrison SA, Wong WS, Francque S, Goodman Z, et al. Cenicriviroc treatment for adults with nonalcoholic steatohepatitis and 
fibrosis: final analysis of the phase 2b CENTAUR study. Hepatology. (2020) 72:892-905. doi: 10.1002/hep.31108

244. Anstee QM, Neuschwander-Tetri BA, Wong VW, Abdelmalek MF, Younossi $\mathrm{ZM}$, Yuan J, et al. Cenicriviroc for the treatment of liver fibrosis in adults with nonalcoholic steatohepatitis: AURORA Phase 3 study design. Contemp Clin Trials. (2020) 89:105922. doi: 10.1016/j.cct.2019.105922

245. AURORA: Phase 3 Study for the Efficacy Safety of CVC for the Treatment of Liver Fibrosis in Adults With NASH. Available online at: https:// ClinicalTrials.gov/show/NCT03028740

246. Chalasani N, Abdelmalek MF, Garcia-Tsao G, Vuppalanchi R, Alkhouri N, Rinella M, et al. Effects of belapectin, an inhibitor of galectin-3, in patients with nonalcoholic steatohepatitis with cirrhosis and portal hypertension. Gastroenterology. (2020) 158:1334-45.e5. doi: 10.1053/j.gastro.2019.11.296

247. Sciacchitano S, Lavra L, Morgante A, Ulivieri A, Magi F, De Francesco GP, et al. Galectin-3: one molecule for an alphabet of diseases, from A to Z. Int $J$ Mol Sci. (2018) 19:379. doi: 10.3390/ijms19020379

248. Karlsson A, Christenson K, Matlak M, Björstad Å, Brown KL, Telemo E, et al. Galectin-3 functions as an opsonin and enhances the macrophage clearance of apoptotic neutrophils. Glycobiology. (2008) 19:16-20. doi: 10.1093/glycob/cwn104

249. Henderson NC, Mackinnon AC, Farnworth SL, Poirier F, Russo FP, Iredale JP, et al. Galectin-3 regulates myofibroblast activation and hepatic fibrosis. Proc Natl Acad Sci USA. (2006) 103:5060-5. doi: 10.1073/pnas.0511167103

250. Traber PG, Zomer E. Therapy of experimental NASH and fibrosis with galectin inhibitors. PLoS ONE. (2013) 8:e83481. doi: 10.1371/journal.pone. 0083481

251. Harrison SA, Marri SR, Chalasani N, Kohli R, Aronstein W, Thompson GA, et al. Randomised clinical study: GR-MD-02, a galectin-3 inhibitor, vs. placebo in patients having non-alcoholic steatohepatitis with advanced fibrosis. Alimentary Pharmacol Therap. (2016) 44:1183-98. doi: 10.1111/apt.13816

252. Study Evaluating the Efficacy and Safety of Belapectin for the Prevention of Esophageal Varices in NASH Cirrhosis. Available online at: https:// ClinicalTrials.gov/show/NCT04365868.

253. Dapito DH, Mencin A, Gwak GY, Pradere JP, Jang MK, Mederacke I, et al. Promotion of hepatocellular carcinoma by the intestinal microbiota and TLR4. Cancer Cell. (2012) 21:504-16. doi: 10.1016/j.ccr.2012.02.007

254. Schneider KM, Bieghs V, Heymann F, Hu W, Dreymueller D, Liao L, et al. CX3CR1 is a gatekeeper for intestinal barrier integrity in mice: Limiting steatohepatitis by maintaining intestinal homeostasis. Hepatology. (2015) 62:1405-16. doi: 10.1002/hep.27982

255. Ju C, Tacke F. Hepatic macrophages in homeostasis and liver diseases: from pathogenesis to novel therapeutic strategies. Cell Mol Immunol. (2016) 13:316-27. doi: $10.1038 / \mathrm{cmi} .2015 .104$

256. Eslamparast T, Poustchi H, Zamani F, Sharafkhah M, Malekzadeh R, Hekmatdoost A. Synbiotic supplementation in nonalcoholic fatty liver disease: a randomized, double-blind, placebo-controlled pilot study. Am J Clin Nutr. (2014) 99:535-42. doi: 10.3945/ajcn.113.068890

257. Kobyliak N, Abenavoli L, Mykhalchyshyn G, Kononenko L, Boccuto L, Kyriienko D, et al. A multi-strain probiotic reduces the fatty liver index, cytokines and aminotransferase levels in NAFLD patients: evidence from a randomized clinical trial. J Gastrointestin Liver Dis. (2018) 27:41-9. doi: 10.15403/jgld.2014.1121.271.kby

258. Marra F, Tacke F. Roles for chemokines in liver disease. Gastroenterology. (2014) 147:577-94.e1. doi: 10.1053/j.gastro.2014.06.043

259. Svendsen P, Graversen JH, Etzerodt A, Hager H, Røge R, Grønbæk H, et al. Antibody-directed glucocorticoid targeting to CD163 in M2-type macrophages attenuates fructose-induced liver inflammatory changes. Mol Ther Methods Clin Dev. (2017) 4:50-61. doi: 10.1016/j.omtm.2016.11.004

260. Bartneck M, Scheyda KM, Warzecha KT, Rizzo LY, Hittatiya K, Luedde $\mathrm{T}$, et al. Fluorescent cell-traceable dexamethasone-loaded liposomes for the treatment of inflammatory liver diseases. Biomaterials. (2015) 37:367-82. doi: $10.1016 /$ j.biomaterials.2014.10.030

261. Li W, He F. Infusion of kupffer cells expanded in. Cell Transplant. (2021) 30:9636897211004090. doi: 10.1177/09636897211004090

262. Thomas JA, Pope C, Wojtacha D, Robson AJ, Gordon-Walker TT, Hartland $\mathrm{S}$, et al. Macrophage therapy for murine liver fibrosis recruits host effector cells improving fibrosis, regeneration, and function. Hepatology. (2011) 53:2003-15. doi: 10.1002/hep.24315

263. Moore JK, Mackinnon AC, Wojtacha D, Pope C, Fraser AR, Burgoyne $\mathrm{P}$, et al. Phenotypic and functional characterization of macrophages with therapeutic potential generated from human cirrhotic monocytes in a cohort study. Cytotherapy. (2015) 17:1604-16. doi: 10.1016/j.jcyt.2015. 07.016

264. Diehl AM, Harrison S, Caldwell S, Rinella M, Paredes A, Moylan C, et al. JKB-121 in patients with nonalcoholic steatohepatitis: A phase 2 double blind randomized placebo control study. J Hepatol. (2018) 68:S103. doi: $10.1016 / S 0168-8278(18) 30425-2$

265. Trial to Examine the Effect of Two Doses of GRI-0621 in Patients With Chronic Liver Disease. Available online at: https://ClinicalTrials.gov/show/ NCT02949375.

266. Puengel T, De Vos S, Hundertmark J, Kohlhepp M, Guldiken N, Pujuguet $\mathrm{P}$, et al. The medium-chain fatty acid receptor GPR84 mediates myeloid cell infiltration promoting steatohepatitis and fibrosis. J Clin Med. (2020) 9:1140. doi: $10.3390 /$ jcm 9041140

267. Du Toit E, Browne L, Irving-Rodgers H, Massa HM, Fozzard N, Jennings MP, et al. Effect of GPR84 deletion on obesity and diabetes development in mice fed long chain or medium chain fatty acid rich diets. Eur J Nutr. (2018) 57:1737-46. doi: 10.1007/s00394-017-1456-5

268. Salmi M, Jalkanen S. Developmental regulation of the adhesive and enzymatic activity of vascular adhesion protein-1 (VAP-1) in humans. Blood. (2006) 108:1555-61. doi: 10.1182/blood-2005-11-4599

269. Weston CJ, Shepherd EL, Claridge LC, Rantakari P, Curbishley SM, Tomlinson JW, et al. Vascular adhesion protein-1 promotes liver inflammation and drives hepatic fibrosis. J Clin Investig. (2015) 125:501-20. doi: $10.1172 / J C I 73722$

270. Shepherd EL, Karim S, Newsome PN, Lalor PF. Inhibition of vascular adhesion protein-1 modifies hepatic steatosis in vitro and in vivo. World $J$ Hepatol. (2020) 12:931-48. doi: 10.4254/wjh.v12.i11.931

271. Different Doses of BI 1467335 Compared to Placebo in Patients With Clinical Evidence of NASH. Available online at: https://ClinicalTrials.gov/ show/NCT03166735.

272. Ilan Y, Shailubhai K, Sanyal A. Immunotherapy with oral administration of humanized anti-CD3 monoclonal antibody: a novel gut-immune systembased therapy for meta-inflammation and NASH. Clin Exp Immunol. (2018) 193:275-83. doi: 10.1111/cei.13159

273. Ilan Y, Maron R, Tukpah AM, Maioli TU, Murugaiyan G, Yang K, et al. Induction of regulatory $\mathrm{T}$ cells decreases adipose inflammation and alleviates insulin resistance in ob/ob mice. Proc Natl Acad Sci USA. (2010) 107:976570. doi: 10.1073/pnas. 0908771107

274. Lalazar G, Mizrahi M, Turgeman I, Adar T, Ben Yảacov A, Shabat Y, et al. Oral administration of OKT3 MAb to patients with NASH, promotes regulatory T-cell induction, and alleviates insulin resistance: results of a phase IIa blinded placebo-controlled trial. J Clin Immunol. (2015) 35:399407. doi: 10.1007/s10875-015-0160-6

Conflict of Interest: The authors declare that the research was conducted in the absence of any commercial or financial relationships that could be construed as a potential conflict of interest.

Publisher's Note: All claims expressed in this article are solely those of the authors and do not necessarily represent those of their affiliated organizations, or those of the publisher, the editors and the reviewers. Any product that may be evaluated in this article, or claim that may be made by its manufacturer, is not guaranteed or endorsed by the publisher.

Copyright (c) 2021 Torre, Motta, Sciorio, Masarone and Persico. This is an openaccess article distributed under the terms of the Creative Commons Attribution License (CC BY). The use, distribution or reproduction in other forums is permitted, provided the original author(s) and the copyright owner(s) are credited and that the original publication in this journal is cited, in accordance with accepted academic practice. No use, distribution or reproduction is permitted which does not comply with these terms. 